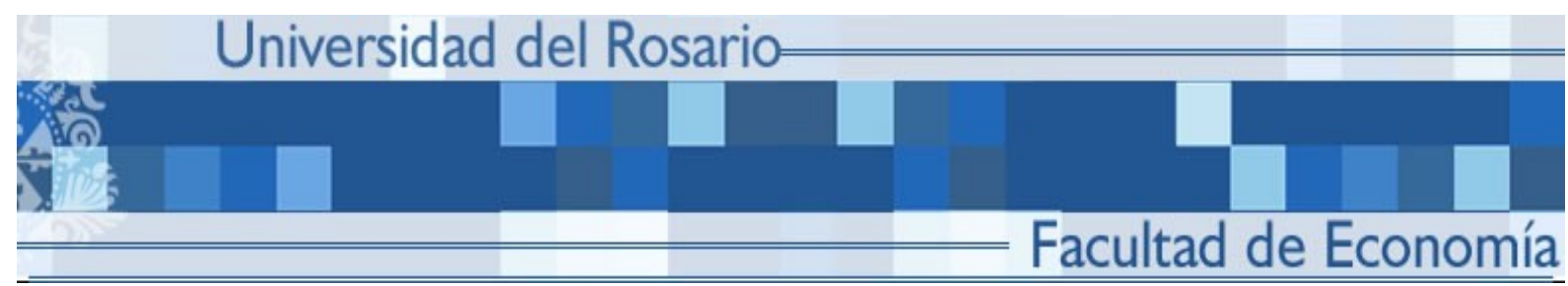

A FIRM-LEVEL ANALYSIS OF ICT ADOPTION IN AN EMERGING ECONOMY: EVIDENCE FROM THE COLOMBIAN MANUFACTURING INDUSTRIES

Juan M. Gallego

Luis H. Gutiérrez

Sang H. Lee

SERIE DOCUMENTOS DE TRABAJO

No. 116

Diciembre 2011 


\title{
A Firm-Level Analysis of ICT Adoption in an Emerging Economy: Evidence from the Colombian Manufacturing Industries
}

\author{
Juan M. Gallego ${ }^{\mathrm{a}}$ \\ Luis H. Gutiérrez $z^{\mathrm{a}^{*}}$, \\ Sang H. Lee ${ }^{b}$ \\ slee@selu.edu \\ Department of Management and Business Administration \\ Southeastern Louisiana University \\ U.S.A. \\ $a$ Department of Economics, Calle 14 No 4-69, University of Rosario, Bogotá, Colombia \\ $b$ Department of Management and Business Administration, Southeastern Louisiana University, \\ U.S.A.
}

\begin{abstract}
This study examines ICT adoption among 3,759 Colombian manufacturing firms, and attempts to identify the factors that are conducive to the adoption and usage of ICT at the firm level. Our major findings are (i) that the adoption of a given information and communication technology is better facilitated when a firm is relatively large, has large human capital, engages in more innovative activities, and when a firm's organizational structure is better aligned with the given technology; (ii) that positive associations between the key determinants and ICT adoptions are more pronounced for small and medium-sized firms than for large ones, and (iii) that information spillovers within industries is also a determinant of ICT adoptions by the firms.
\end{abstract}

Keywords: ICT adoption, Internet, Innovation, Organizational change

\footnotetext{
${ }^{*}$ Corresponding author. Tel.: +5712151734 ; fax: +5712151734

E-mail addresses: luis.gutierrez@urosario.edu.co (L. Gutiérrez), juan.gallego@urosario.edu.co J. Gallego), slee@selu.edu (S. Lee).
} 


\section{Introduction}

After a number of empirical studies linked the high performance of the U.S. economy in the 1990s to its widespread adoption of information and communication technologies (ICT) (Berman et al., 1994; Jorgenson and Stiroh, 2000; McGuckin and Stiroh, 2002; Morrison and Siegel, 1997; Siegel, 1997; Stiroh, 2001), much has been debated about the effects of ICT on firm productivity and profitability (Bartelsman and Doms, 2000; Bresnahan and Trajtenberg, 1995; Brynjolfsson and Hitt, 1996; Brynjolfsson and Yang, 1996). On the other hand, another important conception has been developed in the literature on technological changes: increasing recognition of the complementary relationship among the adoption and usage of ICT, firmspecific factors, and industrial structure. Since Milgrom and Roberts (1990) pioneered the study on the complementary role of firm-specific operational and organizational characteristics as determinants of the adoption of new information technologies at the firm level, a significant amount of the literature has focused on the identification of the factors that are inherent to varying adoption rates across firms of ICTs (Bocquet et al., 2007; Bayo-Moriones and LeraLopez, 2007; Fabiani et al., 2005; Giuri et al., 2008; Hollenstein, 2004; Lucchetti and Sterlacchini, 2004).

The complementarity view, which was missing in the traditional technology diffusion literature, signifies that developing a better understanding of the complementary factors that may facilitate or retard the process of a firm's ICT adoption is an issue of contemporary importance to both managers and policy makers. First, a firm's technological choices are more likely to come to fruition when they are aligned with its operational and organizational readiness for new technologies. Hence it is necessary that managers' efforts to maximize the effectiveness of ICT adoption and usage be concomitant with their organizations' capacity to accommodate to new technologies. Second, the complementarity view may help policy makers gain new insights into the designing industrial policy to promote the usage of new technologies. For instance, firms across different industries face different business environments in terms of market competitiveness and uncertainty so that their incentive to adopt ICT may be influenced by the extent to which industrial policy reflects and conforms to distinct circumstances of their respective industries. Third, the study of complementary factors to boost ICT investments may have some macroeconomic implications as well. There is now quite conclusive evidence of a strong positive correlation between ICT investments and economic performance (Jorgenson and 
Stiroh, 2000; Stiroh, 2001). Although such evidence was obtained mainly from a handful of developed economies, identifying the complementary relationship among the determinants of ICT adoption factors is a topic of relevance to countries at all different stages of economic development, especially emerging economies, for the following reasons. First, an increasing number of emerging economies have been initiating information technology (IT) initiatives and established some form of information and communication systems (Udo and Edoho, 2000). Some anecdotal assessments of IT initiatives appear promising in developing countries like China, Chile, Egypt, India (Indjikian and Siegel, 2005), Colombia (Ministerio de Comunicaciones, 2007), and Venezuela (Ministerio del Poder Popular para Ciencia, Tecnología e Industrias Intermedias, 2007). Second, observed positive impacts on economic performance of ICT in developed countries may signify the importance to emerging economies of investments in ICT as one of the core elements in transition to the knowledge-based economy. Although deficiency in ICT investment with relatively high social opportunity costs is a typical of many emerging and transition countries, several case studies and anecdotal evidence suggest that developing and transition countries have the potential for productivity gains and economic growth from the ICT adoption and usage (Dutta et al., 2003; Humphrey et al., 2003; Lal, 2004; Moodley, 2002; Udo and Edoho, 2000).

This study examines ICT adoption among 3,759 Colombian manufacturing firms, and attempts to identify the factors that are conducive to the adoption and usage of ICT at the firm level. In order to achieve this goal, we use two different data sources from the Colombian Bureau of Statistics (Departamento Nacional de Estadística - DANE): the Colombian Manufacturing Survey (Encuesta Anual Manufacturera - EAM) and the Colombian Innovation Survey II and III (Encuesta de Innovación y Desarrollo Tecnológico - EDIT). Basic ICT-related quantitative observations were collected from the 2006 EAM such as PCs per employee, ICT expenditure per employee, the usage of Internet and its business applications, the size of workforce and its composition along with different level of skills and education, and so on. In addition, observations on firms' internal characteristics such as product innovation and ICT-related organizational changes were compiled from the 2003-2004 EDIT II. Drawing on such a large database, we first construct a number of indicators that are representative of Colombian manufacturing firms across industries, geographical areas, and sizes. With different technology adoption measures as dependent variables, we then develop a basic empirical model which 
investigates not only the complementary relationship between the ICT adoption and a set of firmspecific external and internal factors but also the effects on a firm's ICT adoption of the information spillovers among early ICT adopters and potential users (Griliches, 1957; Mansfield, 1961 and 1989).

Our major findings are (i) that the adoption of a given information and communication technology is better facilitated when a firm is relatively large, a firm has large human capital, a firm engages more innovative activities, and when a firm's organizational structure is more aligned with the given technology; (ii) that positive associations between the key determinants and ICT adoptions are more pronounced for small and medium-sized firms than for large ones, and (iii) that information spillovers within industries is also a determinant of ICT adoptions by the firms.

The rest of this study is organized as follows. In the following section, we review the literature on the ICT adoptions and develop the theoretical framework for the study. The data and the empirical specification are discussed in Section 3 followed by the empirical results in Section 4. Finally, concluding remarks are provided in Section 5.

\section{Empirical background and theoretical framework}

As mentioned in the introduction, the literature on the adoption of ICT has documented a vast amount of empirical evidence of various factors that are inherent to a firm's ICT adoption. Although underlying determinants of a firm's decision to adopt ICT vary across different studies from firm-specific structural characteristics to competitive strategies to industrial or market environment, a general conceptual framework developed from country-specific case studies has focused mainly on the variables in the following five categories: a firm's structural characteristics, human capital, internal organizational characteristics, the characteristics of industrial environment, and the effects of ICT information spillovers. In this section, we provide a brief overview of the literature with emphasis on primary factors of firms' ICT adoption decisions that have been debated and tested in the recent empirical studies.

\subsection{Structural characteristics of firms}

One of the most commonly tested hypotheses in the literature is that a firm's size is positively correlated to ICT adoption with the presumption that larger firms can afford to devote 
more capital and resources to the adoption of ICT than smaller ones. For instance, Premkumar and Roberts (1999) and Geroski (2000) suggest that, given high risks and large costs associated with early adoption of ICT, larger firms are better positioned to take the initiatives in deploying new technologies. In a similar context, Cohen and Levin (1989) argue that large firms are more likely to adopt ICT as they are better prepared to absorb the financial burden of large up-front investment expenditures in ICT thorough economies of scale. Another interesting contribution to the literature in this regard is Hollenstein (2004). Based on a large number of observations on the ICT adoption behavior of Swiss business firms, the study confirms that medium-sized firms have the highest likelihood of ICT adoption. Although a few studies find that the size of firms is either irrelevant or even adverse to firms' ICT initiatives, the main findings in the literature are in support of a positive correlation between the ICT adoption and the size of firms (Delone, 1981; Gretton et al., 2004; Kowtha and Choon, 2001; Lucchetti and Sterlacchini, 2004; Morikawa, 2004).

In addition to the size of firms, some studies in the literature focus on a positive role of multinational ownership in firms' incentive to adopt ICT for the following economic reasoning: First, firms under multinational ownership have not only more financial resources for investments in ICT (Westphal et al., 1997) but also a relatively strong risk management system (Indjikian and Siegel, 2005); Second, multinational firms tend to be more open to external factors (Lai and Guynes, 1997) and benefit more than domestic firms from ICT adoption through enhanced coordination of business activities (Akmanligil and Palvia, 2004; Galliano et al., 2001).

\subsection{Human capital}

Another important implication of ICT adoption at the firm level is that the implementation of new technologies is potentially influenced by individual characteristics of employees such as educational attainment and age. As for the educational level of workers, a common proposition in the literature has been that ICT investment and adoption at the firm level can be facilitated when a firm's workforce is comprised of a relatively large number of higheducated (or high-skilled workers) because the ICT usage and its impact on productivity are likely to increase with the number of workers with higher educational attainment. Such complementary relationship between the adoption of ICT and the educational level of workers has been evidenced in a large number of studies (Arvanitis, 2005; Black and Lynch, 2000; 
Bresnahan et al., 2002; Chapman et al., 2000; Fabiani et al., 2005; Lucchetti and Sterlacchini, 2004; Parente, 1994; Perez et al., 2005; Yap et al., 1992).

While many studies in the literature have used the educational attainment of workers as a proxy for human capital for a firm, a few studies have examined the impact on the ICT adoption of the socio-demographic characteristics of workforce such as age. The presumption is that the inertia of old workforce may become a barrier to ICT adoption because old and more established workforce is often less adaptable and resistant to new changes that often require new skills (Bayo-Moriones and Lera-Lopez, 2007). However the empirical findings on the significance of the impact on ICT adoption of the age composition of workforce are not unambiguous (Beatty et al., 2001; Maliranta and Rouvinen, 2004).

\subsection{Internal organizational structure}

Another principal focus of the literature related to ICT adoption has been on the complementary relationship between the adoption of ICT and firms' organizational characteristics. A primary reasoning behind the organizational complementarity is two-fold: First, the adoption of ICT is likely to be facilitated when a firm's decision-making process is decentralized and its organizational structure is made up of reduced hierarchical levels. This is because productivity gains from ICT adoption are expected to be greater when such decentralized and delayered organizational structure allows for increased information sharing and more effective involvement in decision making among employees (Bayo-Moriones and Lera-Lopez, 2007; Black and Lynch, 2000; Bruque and Moyano, 2007; Bresnahan et al., 2002; Bugamelli and Pagano, 2001; Caroli and Van Reenen, 2001; Fabiani et al., 2005; Falk 2005; Giuri et al., 2008; Williams, 1994). Secondly, several studies have focused on a reverse organizational complementarity that runs from the adoption of ICT to organizational changes (Aghion, 2002; Bresnahan and Trajtenberg, 1995; David and Wright, 1999; Giuri et al., 2008). For example, Giuri et al. (2008) argues that the new systems of production may lead to reorganization of workplace as a secondary innovation because new technologies often increase the benefits and reduce the costs of decentralization and reduced hierarchical layers. However, empirical findings are mixed and controversial across different studies.

\subsection{Industrial environment}


A firm's incentive to adopt ICT may also be affected by the local industrial or market structure. Considering that a firm's decision to undertake investments in innovative technologies is ultimately influenced by the potential profitability of such investments, industrial characteristics pertaining to the firm's profitability prospect will become presumable factors for consideration in ICT investments. The industrial characteristics that have been commonly recognized in the literature as key determinants of ICT adoption include the level of local competition, industry-specific technological opportunities, and the global aspect of the market.

As for the level of competition in a local market or industry, a prevailing presumption in the literature has been that a firm under high competitive pressure is more likely to invest in new technologies as a way of maintaining its competitive edge over rivals. Measures of competitive pressure vary across different studies. For instance, Bayo-Moriones and Lera-Loez (2007) and Baldwin et al. (2004) use a binary variable whereas Hollenstein (2004) captures a firm's exportto-sales ratio as a proxy for competitive pressure. A large number of empirical studies have confirmed a positive role of local competition in the ICT adoption at the firm level (Baldwin et al., 2004; Bayo-Moriones and Lera-Loez, 2007; Bertschek, 1995; Gattington and Robertson, 1989; Hollenstein, 2004).

Several studies have also attempted to link industry-specific technological opportunities to the likelihood of the ICT adoption at the firm level. Propitious industrial environments for the adoption of new technologies have been incorporated into empirical studies in several forms. For instance, Hollenstein (2004) uses firm's assessment of the potential to use ICT on a 5-point Likert scale while Bayo-Moriones and Lera-Loez (2007), Fabiani et al. (2005), and Lucchetti and Sterlacchini (2004) use binary variables to differentiate individual firms across different industries. It is also worth noting that Fabiani et al. (2005) controls for geographical locations of establishments as a way to examine the effect of interactions among firms on the ICT adoption.

Another interesting aspect pertaining to the relationship between industrial environment and ICT adoption is that firms in international markets are more likely to invest in information and communication technologies because they have a strong incentive to reach new customers worldwide via the Internet-based technologies. A positive relationship between the ICT adoption and the global aspect of the market has been evidenced in many empirical studies (Braga and Willmore, 1991; Fabiani et al., 2005; Hollenstein, 2004; Kumar and Saqib, 1996; Teo and Pian, 2003). 


\subsection{Epidemic effects (information spillovers)}

While the complementarity view emphasizes the factors inherent to a firm's structural and organizational characteristics in relation to the firm's ICT adoption decision, the epidemic approach in the literature has focused on the process of technology diffusion across firms within an industry with the presumption: the frequency of contacts between current ICT adopters and potential users increases and so does the likelihood that a firm learns more about a new technology as more firms adopt the technology (Griliches, 1957; Mansfield, 1961, 1963, and 1989). Mansfield (1963), for instance, assumed that the speed at which a technology spreads across firms depends on several firm characteristics such as the number of current users of the technology and the profitability of the technology adoption. However, empirical findings in the literature on the inter-firm technology diffusion are not unanimous, suggesting that information spillovers (or information acquisition) alone may not fully explain the transfer of a technology across firms (Antonelli, 1989; Karshenas and Stoneman, 1993; Colombo and Mosconi, 1995; Swamidass, 2003; Battisti, 2008).

\section{Data, variables and descriptive statistics}

\subsection{Data}

Our empirical analysis uses two sources of data. As mentioned previously, the basic ICTrelated quantitative data are drawn from the Colombian Manufacturing Survey (Encuesta Anual Manufacturera - EAM) conducted yearly by the Colombian Bureau of Statistics (Departamento Nacional de Estadística - DANE) since at least 1970. The survey is carried out on all Colombian manufacturing firms with 20employees and more. The number of firms included in the manufacturing survey was about 5497 out of 7639 establishments for the year 2006. The database for this study is therefore statistically significant and very representative of Colombian manufacturing firms across industries, geographical areas, and sizes. The survey collects information on more than 200 variables but the DANE only provided us with the data of only a subset of them, which are important in our analysis. The EAM comprises quantitative variables on production, sales, number of employees, capital stock, investment, percentage of sales exported, and the like. The main reason for this study to employ the 2006 survey results is that it was the first survey that included a special annex requesting information on ICTs comprising 
access and usage of ICTs by employees, adoption of network technologies, and use of the ICT network for business activities. As shown in Table 1, small and medium firms represent about seventy-two percent of the sample firms in our data set. The distribution of firms across manufacturing sectors is heavily centered on food and tobacco, textiles and leather, and chemicals products. Also, most of firms are located in Bogotá and the so-called Coffee zone.

$<$ PLACE TABLE 1 HERE $>$

The second source of information is the Colombian Innovation Survey II (Encuesta de Innovación y Desarrollo Tecnológico - EDIT) also carried out by the DANE. The EDIT II requested information for the years 2003 and 2004 about innovation inputs and outputs, human capital, and organizational features. Matching the two surveys using the key provided by the DANE, we excluded (i) firms with missing values of main variables in any of the surveys, i.e., the EDIT and the EAM, (ii) firms with abnormal figures either for ICT indicators, sales, investment in ICTs, exports, or for any explanatory variables used in the regressions, and (iii) firms with fewer than 20 employees. After the detection and correction of missing values and outliers in the survey observations, 3,759 sample firms were included in this study. The available information is to a large extent quantitative in nature.

Table 1 also shows a couple of notable observations on the statistics. First, a high degree of heterogeneity has been observed in all ICT indicators across manufacturing sectors as well as across regions. Second, the descriptive statistics reveals that the Colombian manufacturing firms are quite behind their international peers in overall use of ICTs as evidenced, for instance, by Bayo-Moriones and Lera-Lopez (2007). This observation certainly provides a rationale for the study on the key determinants of ICT adoption by Colombian manufacturing firms.

\subsection{Variables and descriptive statistics}

\subsubsection{ICT variables}

The ICT annex of the EAM provides a rich set of ICT indicators as reported in Table 2. We grouped these indicators in three broad intertwined categories as follows: (i) ICTs that increase an employee's productivity, (ii) ICTs that enhance the business performance of a firm as a whole, and (iii) ICTs that improve a firm's connectedness with other businesses and customers. 
The first group of indicators refers to the access to and usage of basic ICTs by a firm's employees. One of such indicators is the number of PCs per worker, denoted by PCs per employee. A couple of interesting observations are made from Table 1. First, the mean number of PCs per worker varies substantially across different segments of the Colombian manufacturing sectors. Second, the standard deviation of the variable for small firms is large relative to those for medium and large ones. Another ICT indicator in the first group is the firm's annual expenditure per employee in hardware and software, denoted by ICT expenditure per employee. The ICT expenditure per employee varies substantially with the size of firms. For instance in Table 1, the ICT expenditure per employee in 2006 averaged $\$ 57$ for large firms compared with only $\$ 19$ for small ones. It is also worth noting that the standard deviation of the variable is large relative to its mean value for the firms of all sizes. Especially for medium-sized firms, its standard deviation is nearly nine times the mean value.

In addition to the number of PCs per worker, the percentage of employees who use PCs specifically for their routine tasks is examined in this study, because PCs may not be required for all employees to perform their regular tasks. Thus this variable, denoted by workers with PCs, is expected to provide us additional insight on the determinants of the ICT adoption. Table 1 indicates that the percentages of employees using PCs on average increases as the size of the firm increases.

The last per-employee ICT indicator of the first group is the percentage of employees who use PCs connected to the Internet, denoted by workers connected to Internet. While it seems more apparent that people in sales department or in the management are more prone to using the Internet for their daily tasks, some engineers and technical workers may also need to be interconnected via the Internet.

The second group of ICT indicators, called the business-performance-enhancing ICT indicators, consists of two dummy variables: (i) whether a firm has access to the Internet, denoted by $d_{-}$Internet, and (ii) whether a firm has its own registered website, denoted by

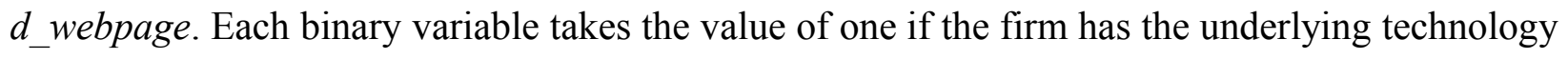
and zero otherwise. Table 1 shows that the percentage of the firms with either the Internet access or own registered websites increases as the firm size increases.

The third group of ICT indicators consists of three ICT indicators that refer to a firm's degree of connectedness with the outside such as other businesses and customers. The first ICT 
indicator of the third group, denoted by $d_{-}$Internet areas, measures the number of functional areas of a firm's business where the Internet is used. We divide a firm's operation into three functional areas such as sales, production, and management. For instance, if a firm uses the Internet in all three functional areas of its operation, the variable will take the value of three. The greater the value of the variable for a firm, the higher is the degree of intra-firm diffusion of the Internet technology.

The second ICT indicator of the third group, Internet applications, measures the number of a firm's responses to the questions whether the Internet is used for (i) ordering raw material, (ii) selling products, (iii) electronic banking, (iv) providing services to customers, and v) distributing products on line. For each question, this indicator takes the value of one if the firm responds "yes" and zero otherwise. Therefore this composite indicator takes a value between zero and five.

The last ICT indicator of a firm's connectedness with other businesses and customers is also a composite one and denoted by networks. This variable adds up three binary responses to the following questions whether a firm has (i) Intranet, (ii) Extranet, and (iii) LAN. For a firm's positive response to each question, the variable takes the value of one and zero otherwise. Thus, if a firm has all three forms of networks, the variable networks will take the value of three. Table 1 shows the larger a firm is, the higher is the degree of its connectedness with other businesses and customers.

Another important aspect of the ICT adoption by the firm that has been extensively examined in the literature is the information spillovers or epidemic effects (Hollenstein, 2004; Battisti and Stoneman, 2003; Battisti et al., 2007; Hollenstein and Woerter, 2008). Hollenstein (2004, p.319) articulates “The epidemic model basically states that a firm's propensity to adopt a technology at a certain point in time is positively influenced by the present (or lagged) level of diffusion in the economy as a whole, or by the proportion of adopters in the industry or sector to which the specific firm is affiliated." Although different indicators have been proposed in that literature, we build upon Hollenstein (2004) and construct a simple indicator of the epidemic effect by calculating the average of each ICT indicator across the manufacturing sector to which the firm is affiliated to as follows: 


$$
\bar{Y}_{j}=\frac{\sum_{i \neq k=1}^{N-1} Y_{j}^{k}}{N_{j}}
$$

In the indicator above, $Y$ refers to one of the nine ICT technologies aforementioned and $j$ indicates the manufacturing sector to which a firm $i$ belongs. The numerator shows the number of firms excluding firm $i$ that have adopted the technology $Y$ while the denominator is the total number of firms in that sector. Thus, for the given technology $Y$, the epidemic effect in sector $j$ is proxied by the sector-specific level of diffusion of the technology relative to firm $i$. This variable is included in all regressions as an additional explanatory variable for the adoption of an ICT by firms.

\subsubsection{Organizational technologies}

The Colombian Innovation Survey (EDIT II) surveyed firms about whether they made investment in any of the five technologies of organizational tools: (i) quality management of products, (ii) Kaisen, (iii) total quality management (TQM), (iv) the enforcement of ISO (international organization for standardization) norms, and (v) other technologies such as good manufacturing practice (GMP), hazard analysis and critical control points (HACCP). We created a binary variable which equals to one if a firm invested at least in one of the five technologies and zero otherwise. It is worth stressing that some research has highlighted concerns over the appropriate timing of the adoption of ICTs and organizational changes. In that regard, we presume that any successful implementation of ICTs within a firm's work system shall be preceded by corresponding organizational changes. Based on this reasoning, this study utilizes the EDIT II survey results for the year 2004. About 31.5\% of the sample firms invested at least in one of the five technologies mentioned above.

As shown in Table 3, pair-wise correlation coefficients across the nine ICT indicators are fairly low unless it is a correlation between a pair of closely-related ICT indicators. For instance, the dummy variable $d$ _Internet is highly correlated with both the categorical variable $d$ _Internet areas and with $d \_w e b p a g e$. Finally, all correlations were statistically significant.

\subsubsection{Human capital}


As discussed previously, a firm's human capital is considered a factor that either facilitates or hinders the adoption and facilitation of ICTs in that a firm's capacity to derive benefits from the technologies is potentially limited by its human capital. In this study we employed two measures of human capital at the firm level: the percentage of workers with a university degree or higher and the ratio of number of technicians to total employees. For the sample firms included in this study, the percentage of workers with higher education averages $14.2 \%$ and the percentage of total employees that are technicians is $16 \%$.

\subsubsection{Other control variables}

In addition to the explanatory variables associated with a firm's organizational technologies and human capital, we incorporate in our analysis a set of variables that are believed to be inherent to a firm's structural characteristics and the industrial environment in which a firm operates. With regard to a firm's structural characteristics, we control for a firm's size and multinational (foreign) ownership. First, the size of a firm is proxied by the logarithm of sales. Among our sample firms, small firms accounted for about 32.5\%, medium-sized firms about $42.4 \%$, and large firms about $25.1 \%$. The number of the sample firms in our study and its distribution across size, regions and manufacturing activities make this study especially pertinent to the study of the ICT adoption by small and medium-sized enterprises (SMEs). Second, the presence of foreign ownership is controlled for by a binary variable which takes the value of one

if foreign capital accounts for at least one percent of a firm's total ownership. The firms with at least one percent foreign ownership accounted for 31\% of the sample firms.

As for the industrial environment in which a firm operates, we control for the global aspect of industrial environment using a firm's export sales as a percentage of its total sales. The economic reasoning behind this is that firms competing in international markets are more likely to adopt ICTs because they have a strong incentive to reach new customers worldwide via the Internet-based technologies. $6.2 \%$ of the sample firms in our study derived part of their sales revenue from the export sales.

Building upon the presumption that the adoption and use of ICTs is better facilitated when a firm is more product-innovation-oriented, we control for a binary variable which equals to one if a firm performed either product or process innovation during the year 2004 and zero 
otherwise. $63 \%$ of the sample firms had some form of product or process-related innovation activity during the year 2004 .

Finally, we included a set of dummy variables for five broad Colombian regions as well as for three sectors of activities of a firm. The five broad Colombian regions are: the Caribbean region composed of seven regional states, the Pacific region composed of three states, the Coffee region composed of fours states, the Central region composed of six states, and Bogota, the capital of the country. The three sectors of activities of a firm are identified according to the OECD low, medium-low and medium-high technology aggregations of manufacturing based on SITC Rev. $3^{1}$.

\section{Empirical strategy}

Based on the recent development in theories and empirical evidence in the literature of the ICT adoption, the following empirical specification is fitted for each of the nine ICT variables $(Y)$ as follows:

$$
Y_{i, j}=\alpha \boldsymbol{X}_{i, j}+\beta \bar{Y}_{j}^{-i}+\gamma \text { ORG }{ }_{i j}+v \mathrm{HC}_{i}+\lambda \mathrm{RA}{ }_{k}+\delta \text { INNO }{ }_{i, j}+\theta \mathrm{TECH}_{i, j}+\eta \mathrm{REG}{ }_{i}+\varepsilon_{i}
$$

In the model above, $i$ refers to a firm and $j$ denotes the manufacturing sector to which the firm is affiliated. $\boldsymbol{X}$ is a vector of three control variables: the logarithm of a firm's sales, a firm's exports as a percentage of its total sales, and the presence of foreign ownership. $\bar{Y}_{j}{ }^{i}$ is the spillover effect of the ICT diffusion within the manufacturing sector $j$ where the firm $i$ belongs. The binary variable $O R G$ indicates whether a firm invested at least in one of the five technologies of organizational tools. $H C$ is a set of two human capital-related measures: the percentage of workers with a university degree or higher and the ratio of number of technicians to total employees. $C R 4$, the four-firm concentration ratio, measures the share of total output accounted for by the four largest firms in the manufacturing sector $j$ where the firm $i$ is affiliated. The binary variable $I N N O$ indicates if a firm performed either product or process innovation during the year 2004. TECH is a set of three dummy variables, each of which refers to whether the firm $i$ is located in medium-high, medium-low or low technological sector. Finally, the variable $R E G$

${ }^{1}$ See OECD (1999). SITC Rev. 3 stands for standard international trade classification. The OECD classifies industries based on technological intensity and proposes four groups. We end up with only three groups since we believe there are no high technology manufacturing sectors in Colombia. 
is a set of dummies that control for the location of the firm $i$ among the five broad Colombian regions.

Given the cross-sectional nature of our data set and the three different types of our dependent variables, the following three econometric techniques are used to explain the ICT adoption by Colombian manufacturing firms. First, the ordinary least squares (OLS) method is used for the first group of quantitative ICT indicators which are directly related to workers' productivity. Second, probit regression is used for the binary variables for a firm's Internet access and its own registered website. Last, the ordered probit regression estimation is employed for the analysis of the three categorical indicators of firm's connectedness with other businesses and customers. All estimates are robust standard errors clustered by Colombian industrial sectors. All estimation results are reported first for the entire sample firms and then for the two sub-samples: large firms only and small and medium-sized firms.

\subsection{ICTs related to employees' performance}

Table 4 presents estimation results for each of the four measures of ICTs that we claim directly affect the performance of a firm's workers. Consistent with the empirical findings in previous country-specific studies (for example, Fabiani et al., 2005 and Haller and Siedschlag, 2008) as well as the theoretical analysis of Cohen and Levinthal (1989), human capital variables are found to be the most significant factors in the adoption of PCs by a firm. First, the percentage of workers with a university degree or higher is highly and positively associated with all of the four ICT indicators in the first group: the number of PCs per worker, a firm's annual expenditure per employee in hardware and software, the percentage of employees who use PCs specifically for their routine tasks, and the percentage of employees who use PCs connected to the Internet.

Second, the other measure of human capital, the ratio of number of technicians to total employees, is found to be positively related to the three ICT indicators except for a firm's annual expenditure per employee in hardware and software. This finding highlights the importance in the ICT adoptions of strengthening human capital within firms and is consistent with the notion of absorptive capacity of Cohen and Levinthal (1990): "the prior related knowledge to assimilate and use new knowledge."

$<$ PLACE TABLE 4 HERE $>$ 
A second factor that facilitates the use of PCs and the Internet is firm size, proxied by the logarithm of a firm's sales. The firm size is found to be highly and positively associated with all four ICT indicators in the first group. A firm's previous efforts to achieve product or process innovation as well as the implementation of some organizational changes within the firm are also found to be effective determinants of a firm's adoption of the ICTs that enhance workers' performance.

For the entire sample firms, the presence of foreign capital in a firm's ownership also facilitates the adoption of ICTs. It is found that a firm with a relative high ratio of exports to sales is likely to have more workers directly connected to the Internet. However, the technological level of a particular manufacturing sector to which a firm belongs does not appear to have any influence in the firm's adoption of these ICTs. The concentration ratio of the four largest firms in a manufacturing sector is found to be negatively related to all firm's ICT adoptions although it is marginally statistically significant only for the indicator of workers connected to the Internet.

Last, as shown in Table 4, positive epidemic effects are confirmed, implying that the greater the number of firms that adopted a given ICT, the more facilitated is the adoption of technology by peer firms within the manufacturing sector. Its significance is more pronounced not only by the positive sign but also the magnitude of estimated coefficient across all dependent variables.

Table 5 shows the estimation results first for large sample firms only and then for small and medium-sized firms, respectively. The main idea behind splitting the data set into two sample groups is to see whether the explanatory power of each control variable distinctively varies with the size of firms. It appears that the level of education in a firm's workforce and its efforts to align organizational changes with the ICTs are all positively associated with the adoption of these ICTs regardless the size of the firm. Last, the overall information spillover effects seem to be more pronounced for small and medium-sized firms than for large ones.

$<$ PLACE TABLE 5 HERE $>$ 
In a nut shell, our empirical findings suggest that the adoption of an ICT is better facilitated not only when a firm is larger with more human capital and modern organizational structure but also when a firm is more innovation-oriented and belongs to a manufacturing sector with a relatively high diffusion rate of the given ITC.

\subsection{ICTs that enhance business performance}

In Section 3, we identified and discussed the two business-performance-enhancing ICT indicators: whether a firm has access to the Internet and whether a firm has its own registered website (see Table 2). As expected (see Table 6), a firm's ICT-absorptive capacity, proxied by the two human capital measures, is positively associated with the firm's use of the Internet and webpage. A firm's ratio of exports to sales is found to be of equal importance in a firm's use of the Internet. This finding is consistent with the presumption that a firm competing in international markets has a stronger incentive to use the Internet to stay globally connected. The estimation results also confirm that a firm that implemented technology-complementary organizational changes or engaged in product or process innovation is more likely to adopt the both types of ICTs.

\section{$<$ PLACE TABLE 6 HERE $>$}

When the same empirical specifications are fitted in two different sample groups, the estimation results for small and medium-sized firms in Table 7 are largely consistent with the ones for the entire sample firms in Table 6. However, the estimation results for large sample firms substantially depart from the previous findings. As evidenced in Table 7, most of the explanatory variables are found not significant in the adoption of the Internet and webpage by large firms. One possible explanation to this contrary finding is that, unlike large firms for which the underlying technologies have been adopted for a long while and become mature technologies, small and medium-sized firms may still face more hurdles such as opportunity costs of investments in human capital, innovations, and technology-complementary organizational changes.

$<$ PLACE TABLE 7 HERE $>$ 


\subsection{ICT connectedness of firms}

We previously defined three ICT indicators that measure a firm's degree of connectedness not only within but also with the outside such as other businesses and customers: the number of functional areas of a firm's business where the Internet is used (d_Internet areas), the number of specific Internet applications that a firm uses (Internet applications), and the number of the types of the network structure that a firm employs (networks). As discussed in Section 3, the three ICT indicators are categorical in the sense that each dependent variable takes a larger value as a firm responds "yes" to more categorical questions. As summarized in Table 8, we have found that a firm's degree of connectedness is increasing when the firm's workforce is more educated, the firm engages more in innovation-related activities, the firm has implemented organizational changes that are complementary for the ICTs, the firm competes in international markets, and when the firm is relatively large. The epidemic effects are also found to be positively associated with the adoption of these network technologies, suggesting that the likelihood that a firm learns about a new technology and adopts it increases as more firms within the industry adopt the technology.

$<$ PLACE TABLE 8 HERE $>$

Similar to our empirical findings in the ICTs that enhance business performance in Section 4.2, some explanatory variables are found not significant when the estimation is fitted only for large firms (see Table 9). We believe this finding can be attributed to the following two reasons. First, this study utilizes a cross-sectional data set so that this study has its limitations in explaining the ICT adoption processes when a large firm adopted the underlying network-related technologies earlier. Second, those network-related technologies have not yet become mature for small and medium-sized firms so that many of the explanatory variables such as human capital and organizational changes may be more relevant to the ICT adoption processes of small and medium-sized firms.

$<$ PLACE TABLE 9 HERE $>$ 


\section{Concluding remarks}

The primary purpose of this research is to investigate a firm's ICT adoption process based on a large sample of 3,759 Colombian manufacturing firms in the year 2006. The data employed is representative in terms of their size, regional location, and manufacturing sectors they are affiliated to.

We find robust and persistent empirical evidence that helps us understand the key determinants in the ICT adoption at the firm level. Our main findings summarized in Table 4 suggest that the adoption of a given technology is better facilitated when a firm is relatively large, a firm has large human capital, a firm engages more innovative activities, and when a firm's organizational structure is more aligned with the given technology. It is also worth noting that positive associations between these key determinants and ICT adoptions are more pronounced for small and medium-sized, which account for about two-thirds of the sample firms. Furthermore, consistent with the previous studies of technology diffusion, significant and positive epidemic effects are empirically confirmed.

We believe the implications of these findings are of the utmost importance for public policy interventions. First, most of these ICTs are still at an early stage of adoption and implementation for small and medium-sized firms in an emerging economy like Colombia. Hence the government support through the programs aimed at facilitating the adoption of those ICTs should be given priority. Second, the information spillovers call also for a pro-technology government policy to enhance the network infrastructure such as broadband deployment crucial to the diffusion of ICTs. Third, the presence of a skilled labor force is found to be one of the most significant determinants of a firm's ICT adoption. It is desired that public policy be oriented toward public training programs in ICTs for the current workforce as well as providing basic ICT skills in primary and secondary schooling. Lastly, firms that are export and innovation-oriented are found to be early ICT adopters among the Colombian manufacturing firms. This finding provides further evidence that an emerging economy like Colombia needs public support to spur R\&D and globalization of its economy.

\section{$<$ PLACE TABLE 10 HERE $>$}

\section{Acknowledgements}


The authors are grateful to the Departamento Nacional de Estadística, DANE that kindly provided them with the data to undertake this research.

\section{References}

Aghion, P., 2002. Schumpeterian growth theory and the dynamics of income inequality. Econometrica 70, 855-882.

Akmanligil, M., Palvia, P., 2004. Strategies for global information systems development. Information and Management 42 (1), 45-59.

Antonelli, C., 1989. The role of technological innovations in mixed model of international diffusion of process innovations: the case of open-end spinning rotors. Research Policy $18,273-288$.

Arvanitis, S., 2005. Computerization, workplace organization, skilled labour and firm productivity: evidence for the Swiss business sector. Economic of Innovation and New Technology 14 (4), 225-249.

Baldwin, J., Sabourin, D., Smith, D., 2004. Firm performance in the Canadian food processing sector: the interaction between ICT, advanced technology use and human resource competencies. in: OECD (Ed.), The Economic Impact of ICT: Measurement, Evidence and Implications. OECD, Paris, pp. 153-181.

Bartelsman, E., Doms, M., 2000. Understanding productivity: lessons from longitudinal microdata. Journal of Economic Literature 38 (3), 569-594.

Battisti, G. (2008) "Innovations and the economics of new technology spreading within and across users: gaps and way forward," Journal of Cleaner Production, 16S1, S22-S31.

Battisti, G., Canepa, A., Stoneman, P., 2009. E-Business usage across and within firms in the UK: profitability, externalities and policy. Research Policy 38, 133-143.

Battisti, G., Hollenstein, H., Stoneman, P., Woerter, M., 2007. Inter and intra firm diffusion of ICT in the United Kingdom (UK) and Switzerland (CH): an internationally comparative study bases on form-level data. Economics of Innovation and New Technology 16, 669687.

Battisti, G., Stoneman, P., 2003. Inter and intra firm effects in the diffusion of new process technology. Research Policy 32, 1641-1655. 
Bayo-Morionese, A., Lera-Lopez, F., 2007. A firm-level analysis of determinants of ICT adoption in Spain. Technovation 27, 352-366.

Beatty, R., Shim, J., Jones, M., 2001. Factors influencing corporate web site adoption: a timebased assessment. Information and Management 38 (6), 337-354.

Berman, E., Bound, J., Griliches, Z., 1994. Changes in the demand for skilled labor within U.S. manufacturing: evidence from the annual survey of manufactures. Quarterly Journal of Economics 109, 367-397.

Bertschek, I., 1995. Product and process innovation as a response to increasing imports and foreign direct investment. Journal of Industrial Economics 43, 341-357.

Black, S., Lynch, L., 2004. What's driving the new economy: the benefits of workplace innovation. Economic Journal 114, 97-116.

Bocquet, R., Brossard, O., Sabatier, M., 2007. Complementarities in organizational design and the diffusion of information technologies: An empirical analysis. Research Policy 36, 367-386.

Braga, H., Willmore, L., 1991. Technological imports and technological effort: an analysis of their determinants in Brazilian firms. Journal of Industrial Economics 39 (4), 421-432.

Bresnahan, T., Trajtenberg, M., 1995. General purpose technologies: engines of growth? Journal of Econometrics 65, 83-108.

Bresnahan, T., Brynjolfsson, E., Hitt, L., 2002. Information technology, workplace organization, and the demand for skilled labor: firm-level evidence. Quarterly Journal of Economics $117,339-376$.

Bruque, S., Moyano, J., 2007. Organisational determinants of information technology adoption and implementation in SMEs: The case of family and cooperative firms. Technovation 27 (5), 241-253.

Brynjolfsson, E., Hitt, L., 1996. Paradox lost: Firm level evidence on returns to information systems spending. Management Science, 42, 541-558.

Brynjolfsson, E., Yang, S., 1996. Information technology and productivity: a review of the literature. Advances in Computers, 43, 179-214.

Bugamelli, M., Pagano, P., 2001. Barriers to investment in ICT. Applied Economics, 36, 22752286. 
Caroli, E., Reenen, J., 2001. Skill-biased organizational change? Evidence from a panel of British and French establishments. Quarterly Journal of Economics 116, 1449-1492.

Chapman, P., James-Moore, M., Szczygiel, M., Thompson, D., 2000. Building internet capabilities in SMEs. Logistics Information Management 13, 353-360.

Cohen, W., Levin, R., 1989. Empirical studies of innovation and market structure. in: Schmalensee, R., Willing, R. (Eds.), Handbook of Industrial Organization, Vol. II, North Holland, Amsterdam, pp. 1059-1107.

Cohen, W., Levinthal, D., 1989. Innovation and learning: the two faces of R\&D. Economic Journal 99, 569-596.

Colombo, M., Mosconi, R., 1995. Complementarity and cumulative learning effects in the early diffusion of multiple technologies. Journal of Industrial Economics 63 (11), 13-48.

David, P., Wright, G., 1999. Early twentieth century productivity growth dynamics: an inquiry into the economic history of 'our ignorance.' SIEPR Discussion Paper, No. 98-3, Stanford Institute of Economic Policy Research, Stanford University, Stanford, CA, U.S.A.

Delone, W., 1981. Firm size and characteristics of computer use. MIS Quarterly 5 (4), 65-77.

Dutta, S., Lanvin, B., Paua, F., (Eds.) 2003. The Global Information Report 2002-03: Readiness for the Networked World, New York and Oxford: Oxford University Press.

Fabiani, S., Schivardi, F., Trento, S., 2005. ICT adoption in Italian manufacturing: firm-level evidence. Industrial and Corporate Change 14 (2), 225-249.

Falk, M., 2005. ICT-linked firm reorganization and productivity gains. Technovation 25 (11), $1229-1250$.

Galliano, D., Roux, P., Filippi, M., 2001. Organizational and spatial determinants of ICT adoption: the case of French industrial firms. Environment and Planning 33 (9), 16431663.

Gattignon, H., Robertson, T., 1989. Technology diffusion: an empirical test of competitive effects. Journal of Marketing 53 (1), 35-49.

Geroski, P., 2000. Models of technology diffusion. Research Policy 29, 603-625.

Giuri, P., Torrisi, S., Zinovyeva, N., 2008. ICT, skills, and organizational change: evidence from Italian manufacturing firms. Industrial and Corporate Change 17 (1), 29-64. 
Gretton, P., Gali, J., Parham, D., 2004. The effects of ICTs and complementary innovations on Australian productivity growth. in: OECD (Ed.), The Economic Impact of ICT: Measurement, Evidence and Implications, OECD, Paris, pp. 105-130.

Griliches, Z., 1957. Hybrid corn: an exploration in the economics of technological change, Econometrica 48, 501-522.

Haller, S., Siedschlag, I., 2008. Determinants of ICT adoption: evidence from firm-level data. DYNREG Working Paper 29.

Hollenstein, H. (2004) "Determinants of the adoption of information and communication technologies (ICT): An empirical analysis based on firm-level data for the Swiss business sector, Structural Change and Economic Dynamics, 15, 315-342.

Hollenstein, H., Woerter, M., 2008. Inter and intra-firm diffusion of technology: the example of E-commerce. An analysis based on Swiss firm-level data. Research Policy 37, 545-564.

Humphrey, J., Mansell, R., Pare, D., Schmitz, H., 2003. The reality of E-commerce with developing countries. A report prepared for the Department for International Development's Globalisation \& Poverty Programme jointly by the London School of Economics and the Institute of Development Studies, Sussex, London/Falmer, March.

Indjikian, R., Siegel, D., 2005. The Impact of investment in IT on economic performance: implications for developing countries. World Development 33 (5), 681-700.

Jorgenson, D., Stiroh, K., 2000. Raising the speed limit: US economic growth in the information age. Brookings Papers on Economic Activity, 31(1), 125-236.

Karshenas, M., Stoneman, p., 1993. Rank, stock order and epidemic effects in the diffusion of new process technologies: an empirical model. Rand Journal of Economics 24 (4), $503-$ 528.

Kowtha, N., Choon, T., 2001. Determinants of website development: a study of electronic commerce in Singapore. Information and Management 39 (3), 227-242.

Kumar, N., Saqib, N., 1996. Firm size, opportunities for adaptation and in-house R\&D activity in developing countries: the case of Indian manufacturing. Research Policy 25 (5), 713-722.

Lal, K., 2004. E-business and export behavior: Evidence from Indian firms. World Development, 32(3), 505-517. 
Lai, V., Guynes, J., 1997. An assessment of the influence of organizational characteristics on information technology adoption decision: a discriminative approach. IEEE Transactions on Engineering Management 44 (2), 146-157.

Lucchetti, R., Sterlacchini, A., 2004. The adoption of ICT among SMEs: evidence from an Italian survey. Small Business Economics 23, 151-168.

Maliranta, M., Rouvinen, P., 2004. ICT and business productivity: Finnish micro-level evidence. in: OECD (Ed.), The Economic Impact of ICT: Measurement, Evidence and Implications, OECD, Paris, pp. 213-239.

Mansfield, E., 1961. Technological change and the rate of imitation. Econometrica 29, 741-766.

Mansfield E., 1963. The speed of response of firms to new techniques. Quarterly Journal of Economics 77 (2), 290-309.

Mansfield, E., 1989. The diffusion of industrial robots in Japan and United States. Research Policy 18, 183-192.

McGuckin, R., Stiroh, K., 2002. Computers and productivity: Are aggregation effects important? Economic Inquiry, 40 (1), 42-59.

Milgrom, P., Roberts, J., 1990. The economics of modern manufacturing. American Economic Review 80, 511-528.

Ministerio de Comunicaciones, 2008. Plan Nacional de Tecnologías de la Información y las Comunicaciones, Colombia.

Ministerio del Poder Popular para Ciencia, Tecnología e Industrias Intermedias, 2007. Plan Nacional de Telecomunicaciones, Informática y Servicios Postales - PNTIySP 20072013, Venezuela.

Moodley, S., 2002. Competing in the digital economy? The dynamics and impact of B2B Ecommerce on the South African manufacturing sector. WIDER Discussion Paper, No. 79.

Morikawa, M., 2004. Information technology and the performance of Japanese SMEs. Small Business Economics 23 (3), 171-177.

Morrison, C., Siegel, D., 1997. External capital factors and increasing returns in US manufacturing. The Review of Economics and Statistics 79(4), 647-654.

OECD, 1999. Science, Technology and Industry Scoreboard: Benchmarking Knowledge-Based Economies, Paris: OECD Publishing. 
Parente, S., 1994. Technology adoption, learning-by-doing, and economic growth. Journal of Economic Theory 63, 346-369.

Perez, M., Martınez, A., de Luis, P., Vela, M., 2005. The differences of firm resources and the adoption of teleworking. Technovation 25 (12), 1476-1483.

Premkumar, G., Roberts, M., 1999. Adoption of new information technologies in rural small business. OMEGA - International Journal of Management Science 27 (4), 467-484.

Siegel, D., 1997. The impact of computers on manufacturing productivity growth: A multipleindicators, multiple-causes approach. The Review of Economics and Statistics 79 (1), 6878.

Stiroh, K., 2001. What drives productivity growth? FRBNY Economic Policy Review 16, 37-59.

Swamidass, P., 2003. Modeling the adoption rates of manufacturing technology innovations by small US manufacturers: a longitudinal investigation. Research Policy 32 (3), 351-366.

Teo, T., Pian, Y., 2003. A contingency perspective on Internet adoption and competitive advantage. European Journal of Information Systems 12 (2), 78-92.

Udo, G., Edoho, F., 2000. Information technology transfer to African nations: An economic development mandate. Journal of Technology Transfer 25, 329-342.

Westphal, J., Gulati, R., Shortell, S., 1997. Customization or conformity? An institutional and network perspective on the content and consequences of TQM adoption. Administrative Science Quarterly 42 (2), 366-394.

Williams, L., 1994. Understanding distribution channels: an inter-organizational study of EDI adoption. Journal of Business Logistics 15 (2), 173-203.

Yap, C., Soh, C., Raman, K., 1992. Information systems success factors in small businesses. OMEGA - International Journal of Management Science 20, 597-609. 
Table 1

Descriptive statistics

\begin{tabular}{|c|c|c|c|c|c|c|c|c|c|}
\hline & $\begin{array}{l}\text { PCs per } \\
\text { employee }\end{array}$ & $\begin{array}{c}\text { ICT expenditure } \\
\text { per worker (USD)* }\end{array}$ & LF_PC & Internet & LF_connected & Webpage & $\begin{array}{l}\text { Internet } \\
\text { areas }\end{array}$ & Networks & $\begin{array}{c}\text { Internet } \\
\text { applications }\end{array}$ \\
\hline \multicolumn{10}{|c|}{ SIZE } \\
\hline \multirow{3}{*}{$20-50$} & 1253.0 & 1,304 & 1253 & 1253 & 1253 & 1483 & 1483 & 1253 & 1483 \\
\hline & $15.3 \%$ & 19 & 24 & $81.1 \%$ & 34.2 & $23.7 \%$ & 1.136 & 0.770 & 1.399 \\
\hline & 0.942 & 91 & 24.0 & 0.4 & 37.1 & 0.4 & 1.0 & 0.6 & 1.5 \\
\hline \multirow{3}{*}{$51-200$} & 1778.0 & 1,764 & 1778 & 1778 & 1778 & 1936 & 1936 & 1778 & 1936 \\
\hline & $13.8 \%$ & 39 & 28 & $94.3 \%$ & 45.5 & $48.0 \%$ & 1.786 & 1.037 & 2.095 \\
\hline & 0.402 & 312 & 24.4 & 0.2 & 38.4 & 0.5 & 1.0 & 0.6 & 1.5 \\
\hline \multirow{3}{*}{$>200$} & 1105.0 & 1,038 & 1105 & 1105 & 1105 & 1142 & 1142 & 1105 & 1142 \\
\hline & $12.7 \%$ & 57 & 33 & $98.8 \%$ & 49.7 & $75.2 \%$ & 2.384 & 1.519 & 2.571 \\
\hline & 0.120 & 156 & 25.9 & 0.1 & 34.9 & 0.4 & 0.9 & 0.8 & 1.4 \\
\hline \multicolumn{10}{|c|}{ MANUFACTURING SECTOR } \\
\hline \multirow{3}{*}{ Food and Tobacco } & 973.0 & 952 & 973 & 973 & 973 & 1079 & 1079 & 973 & 1079 \\
\hline & 35.5 & 3,555 & 24.072 & 0.829 & 32.700 & 0.319 & 1.465 & 0.987 & 1.570 \\
\hline & 129.9 & 238 & 22.6 & 0.4 & 35.0 & 0.5 & 1.1 & 0.7 & 1.5 \\
\hline \multirow{3}{*}{ Textiles and leather } & 925.0 & 948 & 925 & 925 & 925 & 1101 & 1101 & 925 & 1101 \\
\hline & 17.4 & 22,522 & 21.579 & 0.839 & 40.565 & 0.326 & 1.311 & 0.883 & 1.503 \\
\hline & 41.5 & 12,820 & 23.8 & 0.4 & 39.7 & 0.5 & 1.1 & 0.6 & 1.5 \\
\hline \multirow{3}{*}{$\begin{array}{l}\text { Wood, paper and } \\
\text { printing }\end{array}$} & 544.0 & 543 & 544 & 544 & 544 & 626 & 626 & 544 & 626 \\
\hline & 36.5 & 4,293 & 36.239 & 0.912 & 45.819 & 0.390 & 1.679 & 1.035 & 2.006 \\
\hline & 128.3 & 13,442 & 29.0 & 0.3 & 36.9 & 0.5 & 1.1 & 0.6 & 1.6 \\
\hline \multirow{3}{*}{$\begin{array}{l}\text { Petroleum and } \\
\text { Chemicals }\end{array}$} & 854.0 & 856 & 854 & 854 & 854 & 921 & 921 & 854 & 921 \\
\hline & 40.8 & 62 & 34.358 & 0.936 & 47.303 & 0.539 & 1.876 & 1.178 & 2.180 \\
\hline & 183.3 & 452 & 26.6 & 0.2 & 37.3 & 0.5 & 1.1 & 0.7 & 1.5 \\
\hline \multirow{3}{*}{$\begin{array}{l}\text { Non-metallic } \\
\text { mineral products }\end{array}$} & 253.0 & 242 & 253 & 253 & 253 & 269 & 269 & 253 & 269 \\
\hline & 24.2 & 25 & 26.534 & 0.893 & 40.980 & 0.476 & 1.729 & 1.134 & 1.803 \\
\hline & 63.1 & 61 & 27.9 & 0.3 & 38.7 & 0.5 & 1.1 & 0.8 & 1.5 \\
\hline \multirow{3}{*}{$\begin{array}{l}\text { Steel products and } \\
\text { Machines }\end{array}$} & 698.0 & 698 & 698 & 698 & 698 & 778 & 778 & 698 & 778 \\
\hline & 16.3 & 34 & 23.795 & 0.865 & 40.224 & 0.432 & 1.504 & 0.936 & 1.801 \\
\hline & 39.8 & 148 & 22.3 & 0.3 & 37.6 & 0.5 & 1.1 & 0.6 & 1.6 \\
\hline \multirow{3}{*}{$\begin{array}{l}\text { Electrical equipment } \\
\text { and other machinery } \\
\text { and equipment n.e.c }\end{array}$} & 169.0 & 172 & 169 & 169 & 169 & 182 & 182 & 169 & 182 \\
\hline & 24.9 & 48 & 32.580 & 0.893 & 48.124 & 0.588 & 1.912 & 1.065 & 2.275 \\
\hline & 46.5 & 154 & 23.8 & 0.3 & 37.9 & 0.5 & 1.2 & 0.7 & 1.7 \\
\hline \multirow{3}{*}{$\begin{array}{l}\text { Motor vehicles, and } \\
\text { other transport } \\
\text { equipment }\end{array}$} & 143.0 & 145 & 143 & 143 & 143 & 160 & 160 & 143 & 160 \\
\hline & 34.3 & 28 & 26.133 & 0.825 & 39.161 & 0.400 & 1.450 & 0.965 & 1.681 \\
\hline & 95.7 & 68 & 25.4 & 0.4 & 38.4 & 0.5 & 1.1 & 0.7 & 1.6 \\
\hline \multirow{3}{*}{ Furniture } & 351.0 & 351 & 351 & 351 & 351 & 381 & 381 & 351 & 381 \\
\hline & 11.5 & 15 & 22.074 & 0.846 & 37.595 & 0.475 & 1.475 & 0.877 & 1.785 \\
\hline & 19.0 & 31 & 21.7 & 0.4 & 38.3 & 0.5 & 1.1 & 0.6 & 1.5 \\
\hline
\end{tabular}

Note: In each column the first raw is number of firms, the second one is the mean and the last one is the standard deviation.

*An exchange rate of $\$ 2261.5$ was used. 
Table 1 (continued)

Descriptive statistics

\begin{tabular}{|c|c|c|c|c|c|c|c|c|c|}
\hline & $\begin{array}{l}\text { PCs per } \\
\text { employee }\end{array}$ & $\begin{array}{c}\text { ICT expenditure } \\
\text { per worker (USD)* }\end{array}$ & LF_PC & Internet & LF_connected & Webpage & $\begin{array}{c}\text { Internet } \\
\text { areas }\end{array}$ & Networks & $\begin{array}{c}\text { Internet } \\
\text { applications }\end{array}$ \\
\hline \multicolumn{10}{|c|}{ REGION } \\
\hline \multirow{3}{*}{ North-Caribbean } & 419.0 & 394 & 419 & 419 & 419 & 444 & 444 & 419 & 444 \\
\hline & 25.9 & 38 & 27.243 & 0.862 & 33.687 & 0.405 & 1.653 & 1.029 & 1.984 \\
\hline & 55.9 & 353 & 23.8 & 0.3 & 34.1 & 0.5 & 1.1 & 0.7 & 1.6 \\
\hline \multirow{3}{*}{ Pacific-East } & 885.0 & 828 & 885 & 885 & 885 & 941 & 941 & 885 & 941 \\
\hline & 31.2 & 52 & 28.559 & 0.873 & 37.879 & 0.400 & 1.607 & 1.046 & 1.801 \\
\hline & 92.7 & 165 & 25.9 & 0.3 & 36.3 & 0.5 & 1.1 & 0.7 & 1.5 \\
\hline \multirow{3}{*}{ Coffe Zone } & 1343.0 & 1,257 & 1,343 & 1,343 & 1,343 & 1,401 & 1,401 & 1,343 & 1,401 \\
\hline & 23.8 & 24 & 25.903 & 0.844 & 41.874 & 0.412 & 1.637 & 0.923 & 1.906 \\
\hline & 67.6 & 86 & 26.23 & 0.36 & 39.56 & 0.49 & 1.11 & 0.71 & 1.58 \\
\hline \multirow{3}{*}{$\begin{array}{l}\text { Central, East and } \\
\text { South-East }\end{array}$} & 516.0 & 644 & 516 & 516 & 516 & 733 & 733 & 516 & 733 \\
\hline & 38.4 & 38 & 25.998 & 0.816 & 34.587 & 0.304 & 1.173 & 1.023 & 1.277 \\
\hline & 223.1 & 159 & 25.6 & 0.4 & 36.1 & 0.5 & 1.2 & 0.8 & 1.5 \\
\hline \multirow{3}{*}{ Bogotá } & 1716.0 & 1,756 & 1,716 & 1,716 & 1,716 & 1,945 & 1,945 & 1,716 & 1,945 \\
\hline & 26.4 & 38 & 27.577 & 0.909 & 45.061 & 0.459 & 1.612 & 1.024 & 1.866 \\
\hline & 105.9 & 319 & 24.5 & 0.3 & 38.0 & 0.5 & 1.1 & 0.6 & 1.6 \\
\hline
\end{tabular}

Note: In each column the first raw is number of firms, the second row is the mean and the third row is the standard deviation.

*An exchange rate of $\$ 2261.5$ was used. 
Table 2

Description of variables

\begin{tabular}{|c|c|c|}
\hline Variable & Description & Data source \\
\hline \multicolumn{3}{|c|}{ ICTs that affect directly Workers performance } \\
\hline PCs per employee & Number of PCs divided by number of workers & EAM 2006 \\
\hline $\begin{array}{l}\log (\mathrm{ICT} \\
\text { expenditure per } \\
\text { worker in USD) }\end{array}$ & Expenditure for hardware and software of ICTs per employee & EAM 2006 \\
\hline $\begin{array}{l}\text { Workers with PCs } \\
(\%)\end{array}$ & Percentage of employees who used PCs in their daily work & EAM 2006 \\
\hline $\begin{array}{l}\text { Workers connected } \\
\text { to Internet }(\%)\end{array}$ & $\begin{array}{l}\text { Percentage of employees with PCs who are connected to } \\
\text { Internet }\end{array}$ & EAM 2006 \\
\hline \multicolumn{3}{|c|}{ ICTs that affect directly overall firm businesses } \\
\hline d_Internet & $\begin{array}{l}\text { Dummy variable equal to one if the firm reported to have } \\
\text { Internet in its premises, and } 0 \text { otherwise }\end{array}$ & EAM 2006 \\
\hline d_webpage & $\begin{array}{l}\text { Dummy variable equal to one if the firm reported to have a } \\
\text { Webpage, and } 0 \text { otherwise }\end{array}$ & EAM 2006 \\
\hline \multicolumn{3}{|c|}{ Firm's Infrastructure in ICTs } \\
\hline d_Internet areas & $\begin{array}{l}\text { Categorical variable running from } 0 \text { to } 3 \text {. It is the sum of the } \\
\text { binary responses, each of which takes the value } 1 \text { if the firm } \\
\text { uses Internet for: i) Management, ii) Production and iii) Sales; } \\
\text { and } 0 \text { otherwise }\end{array}$ & EAM 2006 \\
\hline Networks & $\begin{array}{l}\text { Categorical variable running from } 0 \text { to } 3 \text {. It sums up the binary } \\
\text { responses each of which takes the value of } 1 \text { if the firm has: i) } \\
\text { Intranet, ii) Extranet and iii) LAN; and } 0 \text { otherwise }\end{array}$ & EAM 2006 \\
\hline $\begin{array}{l}\text { Internet } \\
\text { applications }\end{array}$ & $\begin{array}{l}\text { Categorical variable that adds up } 5 \text { binary responses which take } \\
\text { the value of } 1 \text { if the firm adopts the named technology: i) } \\
\text { Ordering raw material, ii) Selling products, iii) electronic } \\
\text { banking, iv) customer services, and v) distribute products on } \\
\text { line ; and } 0 \text { otherwise. }\end{array}$ & EAM 2006 \\
\hline
\end{tabular}

Source: DANE 
Table 2 (continued)

Description of variables

\begin{tabular}{|c|c|c|}
\hline Variable & Description & Data source \\
\hline \multicolumn{3}{|c|}{ Main Explanatory Variables } \\
\hline Size & $\log (2006$ annual sales $)$ & EAM 2006 \\
\hline $\begin{array}{l}\text { \% College } \\
\text { employees }\end{array}$ & Ratio of employees with university degree and higher & EAM 2006 \\
\hline $\begin{array}{l}\text { \% technical } \\
\text { employees }\end{array}$ & Ratio of technician workers to total employees & EAM 2006 \\
\hline Export & Percentage of export over sales & EAM 2006 \\
\hline Foreign & $\begin{array}{l}\text { Dummy variable equal to } 1 \text { if the firm has foreign ownership } \\
\text { greater than } 1 \%\end{array}$ & EAM 2006 \\
\hline Innovation & $\begin{array}{l}\text { Dummy variable equal to } 1 \text { if the firm reported to have had } \\
\text { product or process innovation in } 2004\end{array}$ & EDIT II \\
\hline $\begin{array}{l}\text { Organizational } \\
\text { change }\end{array}$ & $\begin{array}{l}\text { Dummy variable equal to } 1 \text { if the firm reported to have } \\
\text { performed at least one organizational change in } 2004 \text { in: i) } \\
\text { quality management of products, ii) Kaisen, iii) TQM, iv) } \\
\text { Enforcement of ISO norms, and v) others }\end{array}$ & EDIT II \\
\hline Concentration ratio & Sum of production shares of the four greatest firms in each SIC & EAM 2006 \\
\hline Tech & $\begin{array}{l}\text { Dummies for three sectors of activities of the firm, identified } \\
\text { according to the OECD low, medium-low and medium- high } \\
\text { technology aggregations of manufacturing based on NACE } \\
\text { Rev. } 2\end{array}$ & EAM 2006 \\
\hline Region & $\begin{array}{l}\text { Dummies for } 5 \text { regions that clusters } 21 \text { states in which a firm is } \\
\text { located. }\end{array}$ & EAM 2006 \\
\hline
\end{tabular}

Source: DANE 
Table 3

Overall descriptive statistics and correlation matrices

\section{A. ICT Variables}

\begin{tabular}{|c|c|c|c|c|c|c|c|c|c|c|c|}
\hline & Mean & Std. dev. & 1 & 2 & 3 & 4 & 5 & 6 & 7 & 8 & 9 \\
\hline 1. PCs per employee & 13.930 & 54.229 & 1 & & & & & & & & \\
\hline 2. ICT expenditure per employee & 36.486 & 237.180 & $0.0584 *$ & 1 & & & & & & & \\
\hline 3. Workers with PCs (\%) & 27.030 & 25.230 & $0.1589 *$ & $0.2320 *$ & 1 & & & & & & \\
\hline 4. Internet & 0.870 & 0.336 & $0.0556^{*}$ & $0.2648 *$ & $0.3125^{*}$ & 1 & & & & & \\
\hline 5. Workers connected to Internet $(\%)$ & 40.740 & 37.810 & $0.0535^{*}$ & $0.1871 *$ & $0.3914^{*}$ & $0.4089 *$ & 1 & & & & \\
\hline 6. Webpage & 0.410 & 0.492 & $0.0739 *$ & $0.3086^{*}$ & $0.2926^{*}$ & $0.3427^{*}$ & $0.2784 *$ & 1 & & & \\
\hline 7. Internet Areas & 1.560 & 1.110 & $0.0912 *$ & $0.3575^{*}$ & $0.3950^{*}$ & $0.6310^{*}$ & $0.4431 *$ & $0.5554 *$ & 1 & & \\
\hline 8. Networks & 1.000 & 0.687 & $0.0848^{*}$ & $0.3427^{*}$ & $0.3251^{*}$ & $0.4961 *$ & $0.3043 *$ & $0.4203 *$ & $0.5364 *$ & 1 & \\
\hline 9. Internet applications & 1.790 & 1.550 & $0.0734 *$ & $0.2920 *$ & $0.2712 *$ & $0.5015^{*}$ & $0.3330 *$ & $0.4970 *$ & $0.6670 *$ & $0.4194 *$ & 1 \\
\hline
\end{tabular}

$* p<0.01$

\section{B. Explanatory Variables}

\begin{tabular}{|c|c|c|c|c|c|c|c|c|c|}
\hline & Mean & Std. dev. & 1 & 2 & 3 & 4 & 5 & 6 & 7 \\
\hline 1. $\log$ of sales & 14.68 & 1.7665 & 1 & & & & & & \\
\hline 2. Export & 6.207 & 17.113 & $0.3046^{*}$ & 1 & & & & & \\
\hline 3. Foreign & 0.30774 & 0.46159 & $0.4037 *$ & $0.2402 *$ & 1 & & & & \\
\hline 4. Share professional & 14.21 & 16.05 & $0.1047^{*}$ & $0.0483 *$ & $0.0713^{*}$ & 1 & & & \\
\hline 5. Share Technicians & 16.01 & 19.899 & $0.0542 *$ & & $0.0450^{*}$ & & 1 & & \\
\hline 6. Innovation 2005 & 63.33 & 48.194 & $0.2561 *$ & $0.0945^{*}$ & $-0.0851^{*}$ & $0.0371 *$ & & 1 & \\
\hline 7. Organizational & 31.453 & 46.437 & $0.3424^{*}$ & $0.1057^{*}$ & $0.1283^{*}$ & $0.0791 *$ & 0.0298 & $0.3172 *$ & 1 \\
\hline
\end{tabular}


Table 4

ICT adoption affecting employees - all firms

\begin{tabular}{|c|c|c|c|c|}
\hline & PCs per employee & $\begin{array}{c}\log (\mathrm{ICT} \text { expenditure } \\
\text { per worker })\end{array}$ & $\begin{array}{l}\text { Workers with PCs } \\
(\%)\end{array}$ & $\begin{array}{l}\text { Workers connected } \\
\text { to Internet }(\%)\end{array}$ \\
\hline $\log$ of sales & $\begin{array}{c}0.007 * * * \\
(0.002)\end{array}$ & $\begin{array}{c}0.806^{* * *} \\
(0.084)\end{array}$ & $\begin{array}{c}2.256^{* * *} \\
(0.333)\end{array}$ & $\begin{array}{c}.107 * * * \\
(0.517)\end{array}$ \\
\hline$\%$ export & $\begin{array}{c}0.008 \\
(0.009)\end{array}$ & $\begin{array}{c}0.331 \\
(0.439)\end{array}$ & $\begin{array}{c}3.594 \\
(2.254)\end{array}$ & $\begin{array}{c}14.779 * * * \\
(3.728)\end{array}$ \\
\hline $\begin{array}{l}\text { Dummy if foreign } \\
\text { governance }\end{array}$ & $\begin{array}{c}0.025 * * * \\
(0.008)\end{array}$ & $\begin{array}{c}0.601 * * \\
(0.276)\end{array}$ & $\begin{array}{c}7.122 * * * \\
(1.973)\end{array}$ & $\begin{array}{c}1.158 \\
(1.817)\end{array}$ \\
\hline$\%$ college employees & $\begin{array}{c}0.202 * * * \\
(0.015)\end{array}$ & $\begin{array}{c}1.956^{* * * *} \\
(0.515)\end{array}$ & $\begin{array}{l}35.209^{* * *} \\
(3.060)\end{array}$ & $\begin{array}{l}23.716^{* * *} \\
(3.668)\end{array}$ \\
\hline$\%$ technical employees & $\begin{array}{c}0.077 * * * \\
(0.012)\end{array}$ & $\begin{array}{c}0.447 \\
(0.373)\end{array}$ & $\begin{array}{l}15.444 * * * \\
(2.576)\end{array}$ & $\begin{array}{l}10.588^{* * *} \\
(2.646)\end{array}$ \\
\hline Dummy innovation 2004 & $\begin{array}{c}0.005 \\
(0.003)\end{array}$ & $\begin{array}{l}0.253^{*} \\
(0.136)\end{array}$ & $\begin{array}{c}0.777 \\
(0.973)\end{array}$ & $\begin{array}{c}4.455^{* * *} \\
(1.322)\end{array}$ \\
\hline $\begin{array}{l}\text { Dummy Organizational } \\
\text { change }\end{array}$ & $\begin{array}{c}0.011 * * * \\
(0.004)\end{array}$ & $\begin{array}{c}0.703 * * * \\
(0.174)\end{array}$ & $\begin{array}{c}3.511^{* * *} \\
(0.860)\end{array}$ & $\begin{array}{c}0.797 \\
(1.466)\end{array}$ \\
\hline Medium high technology & $\begin{array}{l}-0.001 \\
(0.006)\end{array}$ & $\begin{array}{c}0.282 \\
(0.231)\end{array}$ & $\begin{array}{c}-2.291 * * \\
(1.013)\end{array}$ & $\begin{array}{c}0.961 \\
(1.331)\end{array}$ \\
\hline Medium low technology & $\begin{array}{l}-0.006 \\
(0.006)\end{array}$ & $\begin{array}{c}0.153 \\
(0.208)\end{array}$ & $\begin{array}{l}-1.057 \\
(0.774)\end{array}$ & $\begin{array}{c}0.163 \\
(1.448)\end{array}$ \\
\hline Caribe & $\begin{array}{l}-0.027 \\
(0.021)\end{array}$ & $\begin{array}{c}0.300 \\
(0.646)\end{array}$ & $\begin{array}{c}7.155^{* * *} \\
(1.832)\end{array}$ & $\begin{array}{c}1.852 \\
(6.784)\end{array}$ \\
\hline Pacifico & $\begin{array}{l}-0.001 \\
(0.022)\end{array}$ & $\begin{array}{c}3.198 * * * \\
(0.726)\end{array}$ & $\begin{array}{l}12.639 * * * \\
(1.227)\end{array}$ & $\begin{array}{c}9.861 \\
(6.578)\end{array}$ \\
\hline Cafetera & $\begin{array}{l}-0.006 \\
(0.023)\end{array}$ & $\begin{array}{c}0.295 \\
(0.720)\end{array}$ & $\begin{array}{l}13.191 * * * \\
(1.652)\end{array}$ & $\begin{array}{c}14.326 * * \\
(6.189)\end{array}$ \\
\hline Central & $\begin{array}{l}-0.006 \\
(0.023)\end{array}$ & $\begin{array}{c}0.953 \\
(0.690)\end{array}$ & $\begin{array}{l}10.792 * * * \\
(2.093)\end{array}$ & $\begin{array}{c}5.485 \\
(7.124)\end{array}$ \\
\hline Bogota & $\begin{array}{l}-0.000 \\
(0.022)\end{array}$ & $\begin{array}{c}0.893 \\
(0.672)\end{array}$ & $\begin{array}{c}10.761^{* * * *} \\
(1.426)\end{array}$ & $\begin{array}{c}14.705^{* *} \\
(6.059)\end{array}$ \\
\hline CR4 & $\begin{array}{l}-0.006 \\
(0.010)\end{array}$ & $\begin{array}{l}-0.403 \\
(0.366)\end{array}$ & $\begin{array}{l}-0.984 \\
(1.447)\end{array}$ & $\begin{array}{l}-5.041^{*} \\
(2.637)\end{array}$ \\
\hline $\begin{array}{l}\text { Spillover of PCs per } \\
\text { employee }\end{array}$ & $\begin{array}{c}0.239 * * * \\
(0.029)\end{array}$ & & & \\
\hline $\begin{array}{l}\text { Spillover of ICT expenditure } \\
\text { per worker }\end{array}$ & & $\begin{array}{l}0.199 * \\
(0.101)\end{array}$ & & \\
\hline Spillover of LF_PC & & & $\begin{array}{c}0.541 * * * \\
(0.056)\end{array}$ & \\
\hline Spillover of LF_connected & & & & $\begin{array}{c}0.242 \\
(0.158)\end{array}$ \\
\hline Constant & $\begin{array}{l}-0.064^{*} \\
(0.035)\end{array}$ & $\begin{array}{c}-8.226 * * * \\
(1.491)\end{array}$ & $\begin{array}{c}-39.924 * * * \\
(4.912)\end{array}$ & $\begin{array}{l}-31.894 * * \\
(13.014)\end{array}$ \\
\hline Observations & 3,759 & 3,759 & 3,759 & 3,759 \\
\hline R-squared & 0.254 & 0.218 & 0.207 & 0.074 \\
\hline
\end{tabular}

Robust standard errors in parentheses $* * * \mathrm{p}<0.01, * * \mathrm{p}<0.05, * \mathrm{p}<0.1$ 
Table 5

ICT adoption affecting employees by firm size - small and medium-sized firms

\begin{tabular}{|c|c|c|c|c|}
\hline & PCs per employee & $\begin{array}{c}\log (\mathrm{ICT} \text { expenditure } \\
\text { per worker })\end{array}$ & $\begin{array}{c}\text { Workers with PCs } \\
(\%)\end{array}$ & $\begin{array}{l}\text { Workers connected } \\
\text { to Internet }(\%)\end{array}$ \\
\hline \multirow[t]{2}{*}{ log of sales } & $0.015 * * *$ & $0.902 * * *$ & $3.453 * * *$ & $5.134 * * *$ \\
\hline & $(0.003)$ & $(0.108)$ & $(0.577)$ & $(0.957)$ \\
\hline \multirow[t]{2}{*}{$\%$ export over sales } & 0.005 & 0.069 & $5.333 * *$ & $12.173^{* * *}$ \\
\hline & $(0.011)$ & $(0.561)$ & $(2.605)$ & $(4.422)$ \\
\hline \multirow[t]{2}{*}{ Dummy if foreign governance } & $0.046^{* * *}$ & $1.107 * *$ & $9.706 * * *$ & $5.461 *$ \\
\hline & $(0.014)$ & $(0.426)$ & $(2.921)$ & $(2.946)$ \\
\hline \multirow[t]{2}{*}{$\%$ college employees } & $0.193 * * *$ & $1.576 * * *$ & $36.658 * * *$ & $23.603 * * *$ \\
\hline & $(0.018)$ & $(0.587)$ & $(3.401)$ & $(4.500)$ \\
\hline \multirow[t]{2}{*}{$\%$ technical employees } & $0.073 * * *$ & 0.585 & $16.223 * * *$ & $14.772 * * *$ \\
\hline & $(0.013)$ & $(0.367)$ & $(3.043)$ & $(3.297)$ \\
\hline \multirow{2}{*}{ Dummy innovation 2004} & 0.004 & 0.234 & 0.701 & $4.114^{* *}$ \\
\hline & $(0.004)$ & $(0.145)$ & $(1.103)$ & $(1.611)$ \\
\hline \multirow[t]{2}{*}{ Dummy Organizational change } & $0.014 * * *$ & $0.787 * * *$ & $4.608 * * *$ & 0.058 \\
\hline & $(0.004)$ & $(0.226)$ & $(1.142)$ & $(1.758)$ \\
\hline \multirow[t]{2}{*}{ Medium high technology } & -0.006 & 0.284 & $-3.730 * * *$ & -0.884 \\
\hline & $(0.006)$ & $(0.205)$ & $(1.373)$ & $(1.735)$ \\
\hline \multirow[t]{2}{*}{ Medium low technology } & -0.007 & 0.067 & -1.782 & -0.953 \\
\hline & $(0.006)$ & $(0.190)$ & $(1.317)$ & $(1.802)$ \\
\hline \multirow[t]{2}{*}{ Caribe } & -0.021 & -0.218 & $7.393 * *$ & 6.730 \\
\hline & $(0.026)$ & $(0.574)$ & $(3.093)$ & $(6.558)$ \\
\hline \multirow{2}{*}{ Pacifico } & 0.002 & $3.083 * * *$ & $13.391 * * *$ & $12.625 * *$ \\
\hline & $(0.026)$ & $(0.622)$ & $(2.372)$ & $(6.278)$ \\
\hline \multirow[t]{2}{*}{ Cafetera } & -0.004 & -0.349 & $14.694 * * *$ & $17.324 * * *$ \\
\hline & $(0.027)$ & $(0.569)$ & $(2.978)$ & $(6.119)$ \\
\hline \multirow[t]{2}{*}{ Central } & -0.005 & 0.206 & $11.029 * * *$ & 7.351 \\
\hline & $(0.028)$ & $(0.570)$ & $(3.331)$ & $(6.883)$ \\
\hline \multirow[t]{2}{*}{ Bogota } & 0.004 & 0.468 & $13.181 * * *$ & $18.912 * * *$ \\
\hline & $(0.026)$ & $(0.525)$ & $(2.610)$ & $(6.014)$ \\
\hline \multirow[t]{2}{*}{ CR4 } & -0.009 & $-0.787 * *$ & -0.406 & -1.213 \\
\hline & $(0.011)$ & $(0.390)$ & $(2.200)$ & $(3.233)$ \\
\hline \multirow[t]{2}{*}{ Spillover of PCs per employee } & $0.244 * * *$ & & & \\
\hline & $(0.028)$ & & & \\
\hline \multirow{2}{*}{$\begin{array}{l}\text { Spillover of ITC expenditure per } \\
\text { employee }\end{array}$} & & $0.240 * * *$ & & \\
\hline & & $(0.089)$ & & \\
\hline \multirow[t]{2}{*}{ Spillover of LF_PC } & & & $0.473 * * *$ & \\
\hline & & & $(0.100)$ & \\
\hline \multirow[t]{2}{*}{ Spillover of LF_connected } & & & & 0.313 \\
\hline & & & & $(0.213)$ \\
\hline \multirow[t]{2}{*}{ Constant } & $-0.172 * * *$ & $-9.221 * * *$ & $-56.901 * * *$ & $-67.856^{* * *}$ \\
\hline & $(0.050)$ & $(1.696)$ & $(8.795)$ & $(17.558)$ \\
\hline Observations & 2,778 & 2,778 & 2,778 & 2,778 \\
\hline R-squared & 0.271 & 0.191 & 0.209 & 0.082 \\
\hline
\end{tabular}

Robust standard errors in parentheses

$* * * \mathrm{p}<0.01, * * \mathrm{p}<0.05, * \mathrm{p}<0.1$ 
Table 5 (continued)

ICT adoption affecting employees by firm size - large firms

\begin{tabular}{|c|c|c|c|c|}
\hline & PCs per employee & $\begin{array}{l}\log (\mathrm{ICT} \text { expenditure } \\
\text { per worker })\end{array}$ & $\begin{array}{l}\text { Workers with PCs } \\
(\%)\end{array}$ & $\begin{array}{l}\text { Workers connected } \\
\text { to Internet }(\%)\end{array}$ \\
\hline \multirow[t]{2}{*}{$\log$ of sales } & $0.016^{* * *}$ & $0.468^{* * *}$ & $2.453^{* * *}$ & 0.590 \\
\hline & $(0.003)$ & $(0.167)$ & $(0.558)$ & (0.649) \\
\hline \multirow[t]{2}{*}{$\%$ export over sales } & 0.016 & 0.777 & 1.107 & $18.190 * * *$ \\
\hline & $(0.019)$ & $(0.532)$ & $(3.881)$ & $(5.504)$ \\
\hline \multirow[t]{2}{*}{ Dummy if foreign governance } & $0.014^{*}$ & 0.370 & $7.001 * * *$ & 1.401 \\
\hline & $(0.007)$ & $(0.282)$ & $(1.943)$ & $(2.157)$ \\
\hline \multirow[t]{2}{*}{$\%$ college employees } & $0.164 * * *$ & $3.067 * * *$ & $24.990 * * *$ & $21.673^{* * *}$ \\
\hline & $(0.023)$ & $(0.898)$ & $(6.419)$ & $(5.547)$ \\
\hline \multirow[t]{2}{*}{$\%$ technical employees } & $0.091 * * *$ & 0.074 & $14.735 * *$ & -1.240 \\
\hline & $(0.022)$ & $(0.945)$ & $(5.955)$ & (5.346) \\
\hline \multirow[t]{2}{*}{ Dummy innovation 2004} & 0.007 & 0.134 & -0.116 & $5.243 *$ \\
\hline & $(0.007)$ & $(0.228)$ & $(1.787)$ & $(2.806)$ \\
\hline \multirow[t]{2}{*}{ Dummy Organizational change } & $0.011 * *$ & $0.607 * *$ & 2.195 & 3.221 \\
\hline & $(0.005)$ & $(0.235)$ & $(1.737)$ & $(2.327)$ \\
\hline \multirow[t]{2}{*}{ Medium high technology } & 0.007 & 0.113 & 0.983 & $6.230^{*}$ \\
\hline & $(0.007)$ & $(0.427)$ & $(2.032)$ & $(3.240)$ \\
\hline \multirow[t]{2}{*}{ Medium low technology } & $-0.014 * *$ & 0.237 & 0.280 & 1.393 \\
\hline & $(0.006)$ & $(0.461)$ & (1.896) & $(1.759)$ \\
\hline \multirow[t]{2}{*}{ Caribe } & 0.009 & 2.419 & $10.778^{*}$ & -9.046 \\
\hline & $(0.020)$ & (1.568) & $(6.006)$ & (11.252) \\
\hline \multirow[t]{2}{*}{ Pacifico } & $0.035^{*}$ & $4.318^{* *}$ & $15.652 * *$ & 3.614 \\
\hline & $(0.021)$ & (1.646) & (6.164) & (11.472) \\
\hline \multirow[t]{2}{*}{ Cafetera } & $0.038^{*}$ & 2.772 & $14.012 * *$ & 7.230 \\
\hline & $(0.022)$ & $(1.816)$ & $(5.901)$ & $(10.382)$ \\
\hline \multirow[t]{2}{*}{ Central } & 0.031 & $3.588^{* *}$ & $13.553 * *$ & 1.034 \\
\hline & $(0.023)$ & $(1.736)$ & $(6.006)$ & (11.370) \\
\hline \multirow{2}{*}{ Bogota } & 0.037 & 2.727 & 8.144 & 2.814 \\
\hline & $(0.024)$ & (1.796) & (5.715) & $(10.320)$ \\
\hline \multirow[t]{2}{*}{ CR4 } & -0.010 & 0.945 & -2.459 & $-14.676^{* * *}$ \\
\hline & $(0.015)$ & $(0.673)$ & $(3.725)$ & $(5.014)$ \\
\hline \multirow[t]{2}{*}{ Spillover of PCs per employee } & $0.219^{* * *}$ & & & \\
\hline & $(0.032)$ & & & \\
\hline \multirow{2}{*}{$\begin{array}{l}\text { Spillover of ICT expenditure per } \\
\text { employee }\end{array}$} & & 0.133 & & \\
\hline & & $(0.165)$ & & \\
\hline Spillover of LF_PC & & & $0.671 * * *$ & \\
\hline \multirow{2}{*}{ Spillover of LF_connected } & & & $(0.091)$ & -0.088 \\
\hline & & & & $(0.131)$ \\
\hline \multirow[t]{2}{*}{ Constant } & $-0.265 * * *$ & -4.517 & $-46.122 * * *$ & $32.604^{*}$ \\
\hline & $(0.062)$ & $(3.260)$ & $(10.049)$ & $(16.805)$ \\
\hline Observations & 981 & 981 & 981 & 981 \\
\hline R-squared & 0.291 & 0.124 & 0.204 & 0.061 \\
\hline
\end{tabular}

Robust standard errors in parentheses

$* * * \mathrm{p}<0.01, * * \mathrm{p}<0.05, * \mathrm{p}<0.1$ 
Table 6

ICT adoption affecting business performance - all firms

\begin{tabular}{|c|c|c|}
\hline & d_Internet & d_webpage \\
\hline $\log$ of sales & $\begin{array}{c}0.294 * * * \\
(0.043)\end{array}$ & $\begin{array}{c}0.265^{* * *} \\
(0.020)\end{array}$ \\
\hline$\%$ export over sales & $\begin{array}{c}0.847^{* *} \\
(0.366)\end{array}$ & $\begin{array}{c}0.251 \\
(0.164)\end{array}$ \\
\hline Dummy if foreign governance & $\begin{array}{l}0.327 * \\
(0.192)\end{array}$ & $\begin{array}{c}0.155 \\
(0.097)\end{array}$ \\
\hline$\%$ college employees & $\begin{array}{c}0.995 * * * \\
(0.342)\end{array}$ & $\begin{array}{l}0.367^{*} \\
(0.191)\end{array}$ \\
\hline$\%$ technical employees & $\begin{array}{c}0.697 * * * \\
(0.241)\end{array}$ & $\begin{array}{c}0.371 * * * \\
(0.112)\end{array}$ \\
\hline Dummy engage innovation 2004 & $\begin{array}{c}0.181 * * * \\
(0.070)\end{array}$ & $\begin{array}{c}0.269 * * * \\
(0.041)\end{array}$ \\
\hline Dummy Organizational change & $\begin{array}{c}0.150^{* *} \\
(0.062)\end{array}$ & $\begin{array}{c}0.275 * * * \\
(0.038)\end{array}$ \\
\hline Medium high technology & $\begin{array}{c}-0.184 * * \\
(0.085)\end{array}$ & $\begin{array}{c}0.173 \\
(0.106)\end{array}$ \\
\hline Medium low technology & $\begin{array}{l}-0.018 \\
(0.082)\end{array}$ & $\begin{array}{c}0.090 \\
(0.085)\end{array}$ \\
\hline Caribe & $\begin{array}{c}0.377 \\
(0.450)\end{array}$ & $\begin{array}{c}0.539^{* *} \\
(0.215)\end{array}$ \\
\hline Pacifico & $\begin{array}{c}0.484 \\
(0.466)\end{array}$ & $\begin{array}{c}0.671 * * * \\
(0.222)\end{array}$ \\
\hline Cafetera & $\begin{array}{c}0.332 \\
(0.466)\end{array}$ & $\begin{array}{c}0.766 * * * \\
(0.218)\end{array}$ \\
\hline Central & $\begin{array}{c}0.177 \\
(0.505)\end{array}$ & $\begin{array}{c}0.601^{* *} \\
(0.259)\end{array}$ \\
\hline Bogota & $\begin{array}{c}0.691 \\
(0.445)\end{array}$ & $\begin{array}{c}0.897 * * * \\
(0.222)\end{array}$ \\
\hline CR4 & $\begin{array}{l}-0.037 \\
(0.202)\end{array}$ & $\begin{array}{c}-0.275^{*} \\
(0.142)\end{array}$ \\
\hline Spillover of Internet & $\begin{array}{c}1.313 * * * \\
(0.419)\end{array}$ & \\
\hline Spillover of Webpage & & $\begin{array}{c}1.076^{* * *} \\
(0.389)\end{array}$ \\
\hline Constant & $\begin{array}{c}-4.699 * * * \\
(0.813)\end{array}$ & $\begin{array}{c}-5.527 * * * \\
(0.335)\end{array}$ \\
\hline Observations & 3,759 & 3,759 \\
\hline
\end{tabular}

Robust standard errors in parentheses

$* * * \mathrm{p}<0.01,{ }^{* *} \mathrm{p}<0.05,{ }^{*} \mathrm{p}<0.1$ 
Table 7

ICT adoption affecting business performance by firm size

\begin{tabular}{|c|c|c|c|c|}
\hline & \multicolumn{2}{|c|}{ Small and medium-sized firms } & \multicolumn{2}{|c|}{ Large Firms } \\
\hline & d_Internet & d_webpage & d_Internet & d_webpage \\
\hline log of sales & $\begin{array}{c}0.316^{* * * *} \\
(0.051)\end{array}$ & $\begin{array}{c}0.216^{* * *} \\
(0.035)\end{array}$ & $\begin{array}{l}-0.125 \\
(0.094)\end{array}$ & $\begin{array}{c}0.131 * * * \\
(0.042)\end{array}$ \\
\hline$\%$ export over sales & $\begin{array}{c}0.779 * * \\
(0.387)\end{array}$ & $\begin{array}{l}0.389 * \\
(0.207)\end{array}$ & $\begin{array}{c}1.486^{*} \\
(0.888)\end{array}$ & $\begin{array}{c}0.098 \\
(0.187)\end{array}$ \\
\hline Dummy if foreign governance & $\begin{array}{c}0.116 \\
(0.204)\end{array}$ & $\begin{array}{l}0.192 * \\
(0.110)\end{array}$ & & $\begin{array}{c}0.124 \\
(0.145)\end{array}$ \\
\hline$\%$ college employees & $\begin{array}{c}1.356^{* * * *} \\
(0.404)\end{array}$ & $\begin{array}{c}0.441 * * \\
(0.218)\end{array}$ & $\begin{array}{l}-0.516 \\
(0.391)\end{array}$ & $\begin{array}{c}0.646 \\
(0.425)\end{array}$ \\
\hline$\%$ technical employees & $\begin{array}{c}0.801 * * * \\
(0.261)\end{array}$ & $\begin{array}{c}0.445 * * * \\
(0.127)\end{array}$ & $\begin{array}{c}0.041 \\
(0.581)\end{array}$ & $\begin{array}{c}0.192 \\
(0.295)\end{array}$ \\
\hline Dummy innovation 2004 & $\begin{array}{c}0.178 * * \\
(0.080)\end{array}$ & $\begin{array}{c}0.294 * * * \\
(0.048)\end{array}$ & $\begin{array}{c}0.345 \\
(0.217)\end{array}$ & $\begin{array}{l}0.125^{*} \\
(0.072)\end{array}$ \\
\hline Dummy Organizational change & $\begin{array}{c}0.152 * * \\
(0.070)\end{array}$ & $\begin{array}{c}0.302 * * * \\
(0.049)\end{array}$ & $\begin{array}{c}0.198 \\
(0.227)\end{array}$ & $\begin{array}{c}0.192 * * * \\
(0.066)\end{array}$ \\
\hline Medium high technology & $\begin{array}{c}-0.225 * * \\
(0.089)\end{array}$ & $\begin{array}{c}0.025 \\
(0.112)\end{array}$ & $\begin{array}{c}0.085 \\
(0.233)\end{array}$ & $\begin{array}{c}0.734 * * * \\
(0.170)\end{array}$ \\
\hline Medium low technology & $\begin{array}{l}-0.059 \\
(0.098)\end{array}$ & $\begin{array}{l}-0.013 \\
(0.090)\end{array}$ & $\begin{array}{c}0.367 \\
(0.377)\end{array}$ & $\begin{array}{c}0.480 * * * \\
(0.119)\end{array}$ \\
\hline Caribe & $\begin{array}{c}0.420 \\
(0.500)\end{array}$ & $\begin{array}{c}0.590 * * \\
(0.232)\end{array}$ & $\begin{array}{c}-4.141 * * * \\
(1.411)\end{array}$ & $\begin{array}{l}-0.016 \\
(0.545)\end{array}$ \\
\hline Pacifico & $\begin{array}{c}0.557 \\
(0.494)\end{array}$ & $\begin{array}{c}0.746 * * * \\
(0.267)\end{array}$ & $\begin{array}{c}-3.951 * * * \\
(1.262)\end{array}$ & $\begin{array}{c}0.139 \\
(0.491)\end{array}$ \\
\hline Cafetera & $\begin{array}{c}0.436 \\
(0.491)\end{array}$ & $\begin{array}{c}0.783 * * * \\
(0.258)\end{array}$ & $\begin{array}{c}-4.427 * * * \\
(1.326)\end{array}$ & $\begin{array}{c}0.332 \\
(0.512)\end{array}$ \\
\hline Central & $\begin{array}{c}0.233 \\
(0.535)\end{array}$ & $\begin{array}{c}0.552 * * \\
(0.279)\end{array}$ & $\begin{array}{c}-4.013^{* * *} \\
(1.451)\end{array}$ & $\begin{array}{c}0.373 \\
(0.548)\end{array}$ \\
\hline Bogota & $\begin{array}{l}0.792 * \\
(0.465)\end{array}$ & $\begin{array}{c}0.949 * * * \\
(0.263)\end{array}$ & $\begin{array}{c}-4.266^{* * *} \\
(1.389)\end{array}$ & $\begin{array}{c}0.340 \\
(0.515)\end{array}$ \\
\hline CR4 & $\begin{array}{c}0.109 \\
(0.214)\end{array}$ & $\begin{array}{l}-0.247 \\
(0.159)\end{array}$ & $\begin{array}{l}-0.751 \\
(0.586)\end{array}$ & $\begin{array}{l}-0.226 \\
(0.247)\end{array}$ \\
\hline Spillover of Internet & $\begin{array}{c}1.487 * * * \\
(0.475)\end{array}$ & & & $\begin{array}{c}0.194 \\
(0.478)\end{array}$ \\
\hline Spillover of Webpage & & $\begin{array}{c}1.431 * * * \\
(0.397)\end{array}$ & $\begin{array}{c}0.286 \\
(0.990)\end{array}$ & \\
\hline Constant & $\begin{array}{c}-5.333 * * * \\
(0.932)\end{array}$ & $\begin{array}{c}-5.063 * * * \\
(0.516)\end{array}$ & $\begin{array}{c}8.151 \\
(0.000)\end{array}$ & $\begin{array}{c}-2.271 * * \\
(0.899)\end{array}$ \\
\hline Observations & 2,778 & 2,778 & 748 & 981 \\
\hline
\end{tabular}

Robust standard errors in parentheses

$* * * \mathrm{p}<0.01, * * \mathrm{p}<0.05, * \mathrm{p}<0.1$ 
Table 8

ICT adoption affecting firm's infrastructure on technology - all firms

\begin{tabular}{|c|c|c|c|}
\hline & d_Internet areas & Internet applications & Networks \\
\hline $\log$ of sales & $\begin{array}{c}0.224 * * * \\
(0.017)\end{array}$ & $\begin{array}{c}0.202 * * * \\
(0.029)\end{array}$ & $\begin{array}{c}0.165^{* * *} \\
(0.010)\end{array}$ \\
\hline$\%$ export over sales & $\begin{array}{c}0.292 * * \\
(0.142)\end{array}$ & $\begin{array}{c}0.353^{* *} \\
(0.152)\end{array}$ & $\begin{array}{c}0.162^{* *} \\
(0.078)\end{array}$ \\
\hline Dummy if foreign governance & $\begin{array}{c}0.005 \\
(0.065)\end{array}$ & $\begin{array}{c}-0.322 * * * \\
(0.086)\end{array}$ & $\begin{array}{l}0.091^{*} \\
(0.046)\end{array}$ \\
\hline$\%$ college employees & $\begin{array}{c}0.585^{* * *} \\
(0.103)\end{array}$ & $\begin{array}{c}0.566 * * * \\
(0.208)\end{array}$ & $\begin{array}{c}0.368 * * * \\
(0.078)\end{array}$ \\
\hline$\%$ technical employees & $\begin{array}{c}0.389 * * * \\
(0.070)\end{array}$ & $\begin{array}{c}0.485 * * * \\
(0.139)\end{array}$ & $\begin{array}{c}0.161^{* * *} \\
(0.050)\end{array}$ \\
\hline Dummy innovation 2004 & $\begin{array}{c}0.139 * * * \\
(0.040)\end{array}$ & $\begin{array}{c}0.198 * * * \\
(0.048)\end{array}$ & $\begin{array}{c}0.066^{* * *} \\
(0.023)\end{array}$ \\
\hline Dummy Organizational change & $\begin{array}{c}0.123 * * * \\
(0.036)\end{array}$ & $\begin{array}{c}0.118 \\
(0.073)\end{array}$ & $\begin{array}{c}0.052^{* *} \\
(0.026)\end{array}$ \\
\hline Medium high technology & $\begin{array}{c}0.002 \\
(0.044)\end{array}$ & $\begin{array}{c}0.043 \\
(0.075)\end{array}$ & $\begin{array}{c}0.031 \\
(0.029)\end{array}$ \\
\hline Medium low technology & $\begin{array}{c}0.011 \\
(0.045)\end{array}$ & $\begin{array}{c}0.063 \\
(0.084)\end{array}$ & $\begin{array}{l}-0.010 \\
(0.027)\end{array}$ \\
\hline Caribe & $\begin{array}{c}0.501 * * * \\
(0.169)\end{array}$ & $\begin{array}{l}0.639 * * \\
(0.304)\end{array}$ & $\begin{array}{c}0.072 \\
(0.129)\end{array}$ \\
\hline Pacifico & $\begin{array}{c}0.518 * * * \\
(0.167)\end{array}$ & $\begin{array}{c}0.458 \\
(0.285)\end{array}$ & $\begin{array}{c}0.167 \\
(0.129)\end{array}$ \\
\hline Cafetera & $\begin{array}{c}0.603 * * * \\
(0.175)\end{array}$ & $\begin{array}{c}0.620^{* *} \\
(0.310)\end{array}$ & $\begin{array}{c}0.076 \\
(0.126)\end{array}$ \\
\hline Central & $\begin{array}{c}0.425^{* *} \\
(0.181)\end{array}$ & $\begin{array}{c}0.374 \\
(0.343)\end{array}$ & $\begin{array}{c}0.109 \\
(0.120)\end{array}$ \\
\hline Bogota & $\begin{array}{c}0.643 * * * \\
(0.156)\end{array}$ & $\begin{array}{c}0.677^{* *} \\
(0.291)\end{array}$ & $\begin{array}{c}0.152 \\
(0.126)\end{array}$ \\
\hline CR4 & $\begin{array}{l}-0.026 \\
(0.089)\end{array}$ & $\begin{array}{l}-0.116 \\
(0.121)\end{array}$ & $\begin{array}{l}-0.025 \\
(0.060)\end{array}$ \\
\hline Spillover of Internet areas & $\begin{array}{c}0.306^{* * *} \\
(0.069)\end{array}$ & & \\
\hline Spillover of Internet applications & & $\begin{array}{c}0.391 * * * \\
(0.099)\end{array}$ & \\
\hline Spillover of Networks & & & $\begin{array}{c}0.198 * * * \\
(0.068)\end{array}$ \\
\hline Constant & $\begin{array}{c}-2.835^{* * *} \\
(0.273)\end{array}$ & $\begin{array}{c}-2.463 * * * \\
(0.479)\end{array}$ & $\begin{array}{c}-1.873 * * * \\
(0.132)\end{array}$ \\
\hline $\begin{array}{l}\text { Observations } \\
\text { R-squared }\end{array}$ & $\begin{array}{l}3,759 \\
0.252\end{array}$ & $\begin{array}{l}3,759 \\
0.107\end{array}$ & $\begin{array}{l}3,759 \\
0.270\end{array}$ \\
\hline
\end{tabular}

Robust standard errors in parentheses

$* * * \mathrm{p}<0.01, * * \mathrm{p}<0.05, * \mathrm{p}<0.1$ 
Table 9

ICT adoption affecting firm's infrastructure on technology - small and medium-sized firms

\begin{tabular}{|c|c|c|c|}
\hline & d_Internet Areas & Internet applications & Networks \\
\hline $\log$ of sales & $\begin{array}{c}0.299 * * * \\
(0.037)\end{array}$ & $\begin{array}{c}0.181 * * * \\
(0.038)\end{array}$ & $\begin{array}{c}0.308 * * * \\
(0.039)\end{array}$ \\
\hline$\%$ export over sales & $\begin{array}{c}0.476^{*} \\
(0.252)\end{array}$ & $\begin{array}{c}0.325 * * \\
(0.144)\end{array}$ & $\begin{array}{c}0.340 * \\
(0.206)\end{array}$ \\
\hline Dummy if foreign governance & $\begin{array}{c}0.179 \\
(0.154)\end{array}$ & $\begin{array}{c}-0.297 * * * \\
(0.101)\end{array}$ & $\begin{array}{c}0.431 * * * \\
(0.097)\end{array}$ \\
\hline$\%$ college employees & $\begin{array}{c}0.946 * * * \\
(0.159)\end{array}$ & $\begin{array}{c}0.543 * * * \\
(0.157)\end{array}$ & $\begin{array}{c}0.911 * * * \\
(0.178)\end{array}$ \\
\hline$\%$ technical employees & $\begin{array}{c}0.634 * * * \\
(0.108)\end{array}$ & $\begin{array}{c}0.413 * * * \\
(0.109)\end{array}$ & $\begin{array}{c}0.436 * * * \\
(0.138)\end{array}$ \\
\hline Dummy innovation 2004 & $\begin{array}{c}0.175 * * * \\
(0.053)\end{array}$ & $\begin{array}{c}0.136^{* * *} \\
(0.044)\end{array}$ & $\begin{array}{c}0.098 * \\
(0.058)\end{array}$ \\
\hline Dummy Organizational change & $\begin{array}{c}0.198 * * * \\
(0.053)\end{array}$ & $\begin{array}{c}0.120 * \\
(0.069)\end{array}$ & $\begin{array}{c}0.196 * * * \\
(0.060)\end{array}$ \\
\hline Medium high technology & $\begin{array}{c}-0.084 \\
(0.057)\end{array}$ & $\begin{array}{c}-0.093 \\
(0.075)\end{array}$ & $\begin{array}{l}-0.006 \\
(0.065)\end{array}$ \\
\hline Medium low technology & $\begin{array}{l}-0.058 \\
(0.061)\end{array}$ & $\begin{array}{l}-0.024 \\
(0.077)\end{array}$ & $\begin{array}{c}-0.093 \\
(0.058)\end{array}$ \\
\hline Caribe & $\begin{array}{c}0.637 * * * \\
(0.207)\end{array}$ & $\begin{array}{c}0.513 \\
(0.314)\end{array}$ & $\begin{array}{c}0.113 \\
(0.272)\end{array}$ \\
\hline Pacifico & $\begin{array}{c}0.802 * * * \\
(0.196)\end{array}$ & $\begin{array}{c}0.465 \\
(0.303)\end{array}$ & $\begin{array}{c}0.392 \\
(0.276)\end{array}$ \\
\hline Cafetera & $\begin{array}{c}0.837 * * * \\
(0.210)\end{array}$ & $\begin{array}{c}0.506 \\
(0.308)\end{array}$ & $\begin{array}{c}0.059 \\
(0.251)\end{array}$ \\
\hline Central & $\begin{array}{c}0.531 * * \\
(0.228)\end{array}$ & $\begin{array}{c}0.320 \\
(0.356)\end{array}$ & $\begin{array}{c}0.028 \\
(0.227)\end{array}$ \\
\hline Bogota & $\begin{array}{c}0.884 * * * \\
(0.182)\end{array}$ & $\begin{array}{c}0.563 * \\
(0.302)\end{array}$ & $\begin{array}{c}0.309 \\
(0.252)\end{array}$ \\
\hline CR4 & $\begin{array}{l}-0.009 \\
(0.126)\end{array}$ & $\begin{array}{l}-0.086 \\
(0.111)\end{array}$ & $\begin{array}{l}-0.117 \\
(0.131)\end{array}$ \\
\hline Spillover of Internet areas & $\begin{array}{c}0.470 * * * \\
(0.108)\end{array}$ & & \\
\hline Spillover of Internet applications & & $\begin{array}{c}0.413 * * * \\
(0.095)\end{array}$ & \\
\hline Spillover of Networks & & & $\begin{array}{c}0.457 * * * \\
(0.154)\end{array}$ \\
\hline Observations & 2,778 & 2,778 & 2,778 \\
\hline
\end{tabular}

Robust standard errors in parentheses

$* * * \mathrm{p}<0.01, * * \mathrm{p}<0.05, * \mathrm{p}<0.1$ 
Table 9 (continued)

ICT adoption affecting firm's infrastructure on technology - large firms

\begin{tabular}{|c|c|c|c|}
\hline & d_Internet areas & Internet applications & Networks \\
\hline $\log$ of sales & $\begin{array}{c}0.147 * * * \\
(0.039)\end{array}$ & $\begin{array}{l}0.059^{* *} \\
(0.028)\end{array}$ & $\begin{array}{c}0.232 * * * \\
(0.037)\end{array}$ \\
\hline$\%$ export over sales & $\begin{array}{c}0.399 * * \\
(0.197)\end{array}$ & $\begin{array}{c}0.213 \\
(0.136)\end{array}$ & $\begin{array}{c}0.348^{* *} \\
(0.178)\end{array}$ \\
\hline Dummy if foreign governance & $\begin{array}{c}0.012 \\
(0.114)\end{array}$ & $\begin{array}{c}-0.186^{* *} \\
(0.076)\end{array}$ & $\begin{array}{l}-0.029 \\
(0.094)\end{array}$ \\
\hline$\%$ college employees & $\begin{array}{c}0.886 * * * \\
(0.309)\end{array}$ & $\begin{array}{c}0.325 \\
(0.213)\end{array}$ & $\begin{array}{c}0.674^{* * * *} \\
(0.232)\end{array}$ \\
\hline$\%$ technical employees & $\begin{array}{c}0.259 \\
(0.272)\end{array}$ & $\begin{array}{l}0.422 * \\
(0.235)\end{array}$ & $\begin{array}{c}0.114 \\
(0.183)\end{array}$ \\
\hline Dummy innovation 2004 & $\begin{array}{c}0.041 \\
(0.084)\end{array}$ & $\begin{array}{c}0.121 \\
(0.093)\end{array}$ & $\begin{array}{c}0.366^{* * * *} \\
(0.095)\end{array}$ \\
\hline Dummy Organizational change & $\begin{array}{c}0.080 \\
(0.069)\end{array}$ & $\begin{array}{c}0.044 \\
(0.065)\end{array}$ & $\begin{array}{l}-0.058 \\
(0.082)\end{array}$ \\
\hline Medium high technology & $\begin{array}{c}0.330^{* *} \\
(0.140)\end{array}$ & $\begin{array}{c}0.363 * * * \\
(0.109)\end{array}$ & $\begin{array}{l}0.194 * * \\
(0.094)\end{array}$ \\
\hline Medium low technology & $\begin{array}{c}0.257 * * * \\
(0.097)\end{array}$ & $\begin{array}{c}0.231 * * * \\
(0.080)\end{array}$ & $\begin{array}{l}0.133^{*} \\
(0.080)\end{array}$ \\
\hline Caribe & $\begin{array}{c}0.458 \\
(0.482)\end{array}$ & $\begin{array}{c}0.128 \\
(0.186)\end{array}$ & $\begin{array}{l}-0.236 \\
(0.482)\end{array}$ \\
\hline Pacifico & $\begin{array}{c}0.101 \\
(0.474)\end{array}$ & $\begin{array}{l}-0.172 \\
(0.193)\end{array}$ & $\begin{array}{l}-0.085 \\
(0.482)\end{array}$ \\
\hline Cafetera & $\begin{array}{c}0.355 \\
(0.458)\end{array}$ & $\begin{array}{c}0.107 \\
(0.180)\end{array}$ & $\begin{array}{l}-0.062 \\
(0.481)\end{array}$ \\
\hline Central & $\begin{array}{c}0.317 \\
(0.469)\end{array}$ & $\begin{array}{l}-0.051 \\
(0.176)\end{array}$ & $\begin{array}{c}0.210 \\
(0.479)\end{array}$ \\
\hline Bogota & $\begin{array}{c}0.388 \\
(0.470)\end{array}$ & $\begin{array}{c}0.125 \\
(0.175)\end{array}$ & $\begin{array}{l}-0.033 \\
(0.487)\end{array}$ \\
\hline CR4 & $\begin{array}{c}0.218 \\
(0.264)\end{array}$ & $\begin{array}{l}-0.000 \\
(0.198)\end{array}$ & $\begin{array}{c}0.095 \\
(0.177)\end{array}$ \\
\hline Spillover of Internet areas & $\begin{array}{c}0.163 \\
(0.216)\end{array}$ & & \\
\hline Spillover of Internet applications & & $\begin{array}{c}0.005 \\
(0.130)\end{array}$ & \\
\hline Spillover of Networks & & & $\begin{array}{c}0.481^{* *} \\
(0.218)\end{array}$ \\
\hline Observations & 981 & 981 & 981 \\
\hline
\end{tabular}

Robust standard errors in parentheses

$* * * \mathrm{p}<0.01,{ }^{* *} \mathrm{p}<0.05,{ }^{*} \mathrm{p}<0.1$ 
Table 10

Summary of overall findings

\begin{tabular}{|c|c|c|c|c|c|c|c|c|}
\hline ICTs & Sales & Export & Foreign & Professionals & Technicians & $\begin{array}{l}\text { Innovators } \\
\text { in } 2005\end{array}$ & $\begin{array}{c}\text { Organizational } \\
\text { Changes in } 2005\end{array}$ & $\begin{array}{c}\text { Epidemic } \\
\text { Effects }\end{array}$ \\
\hline PCs per employee & $+* * *$ & + & $+* * *$ & $+* * *$ & $+* * *$ & $+* * *$ & $+* * *$ & $+* * *$ \\
\hline $\begin{array}{l}\text { ICT expenditure per } \\
\text { employee }\end{array}$ & $+* * *$ & + & $+* *$ & $+* * *$ & + & $+* * *$ & $+* * *$ & $+* * *$ \\
\hline Workers with PCs (\%) & $+* * *$ & + & $+* * *$ & $+* * *$ & $+* * *$ & $+* * *$ & $+* * *$ & $+* * *$ \\
\hline $\begin{array}{l}\text { Workers connected to } \\
\text { Internet }(\%)\end{array}$ & $+* * *$ & $+* *$ & + & $+* * *$ & $+* * *$ & + & + & $+* * *$ \\
\hline Internet & $+* * *$ & $+* *$ & + & $+* * *$ & $+* *$ & $+* *$ & $+* * *$ & $+* * *$ \\
\hline Webpage & $+* * *$ & + & $+*$ & $+*$ & $+* * *$ & $+* * *$ & $+* * *$ & $+* * *$ \\
\hline Internet areas & $+* * *$ & $+* *$ & + & $+* * *$ & $+* * *$ & $+* * *$ & $+* * *$ & $+* * *$ \\
\hline Networks & $+* * *$ & $+* *$ & $-* *$ & $+* * *$ & $+* * *$ & $+* * *$ & $+*$ & $+* * *$ \\
\hline Internet applications & $+* * *$ & $+* *$ & $+^{*}$ & $+* * *$ & $+* * *$ & $+* * *$ & $+* *$ & $+* * *$ \\
\hline
\end{tabular}

Along a given ICT, each cell shows the sign of the estimated coefficient of an explanatory variable and the level of statistical significance, respectively. $* * * \mathrm{p}<0.01, * * \mathrm{p}<0.05, * \mathrm{p}<0.1$ 